\title{
Seasonal quantitative dynamics and ecology of pelagic rotifers in an acidified boreal lake
}

\author{
Svein Birger WÆRVÅGEN,,$^{1 *}$ Tom ANDERSEN ${ }^{2}$ \\ ${ }^{1}$ Department of Natural Sciences and Technology, Inland Norway University of Applied Sciences, Campus Hamar, 2318 Hamar; \\ ${ }^{2}$ Department of Biosciences, University of Oslo, Blindernvn 31, 0371 Oslo, Norway \\ *Corresponding author: svein.warvagen@inn.no
}

\begin{abstract}
Lake Gjerstadvann is a dimictic, oligotrophic, slightly acidified boreal lake in southern Norway (northwest Europe). The planktonic rotifer community of this lake was studied quantitatively during one year in order to investigate the impacts of the local environment and biotic interactions on seasonal succession and habitat selection. Pure suspension feeders (mainly Keratella spp., Conochilus spp., and Kellicottia longispina) together with raptorial graspers or specialised feeders (mainly Polyarthra spp. and Collotheca spp.) dominated the rotifer community over prolonged periods, whereas carnivorous/omnivorous species (mainly $A s-$ planchna priodonta) were extremely uncommon. Low bicarbonate buffering capacity resulted in a distinctive seasonal oscillating $\mathrm{pH}$ between 5.0 and 5.6, defining a special acid-transition lake category. The $\mathrm{pH}$ values were highest in the productive period during summer, and lowest during ice break-up coinciding with the peak reactive aluminium concentrations of $250-300 \mu \mathrm{g} \mathrm{L}{ }^{-1}$. As in typical Norwegian boreal perch lakes, the most abundant cladoceran was Bosmina longispina due to perch predation on the genus Daphnia. Rotifer community structure was significantly related to temperature and oxygen $(\mathrm{P}=0.001$ and $\mathrm{P}=0.022)$, illustrating the important effects of the seasonal cycle and vertical density stratification. The most significant competition indicator species were B. longispina and Eudiaptomus gracilis (both with $\mathrm{P}=0.001$ ). A variance partitioning indicated that $14 \%$ of the total community composition variance could only be explained by biotic interactions, while $19 \%$ of the variance could be attributed to environmental gradients. Of the variance, $23 \%$ could not be resolved between biotic interactions and environmental gradients, while a residual of $44 \%$ was not explainable by any of the variables. Acid conditions alone cannot account for all the observed changes in the rotifer community of this lake with low humic content, since resource limitation and food competition are also important factors shaping rotifer population dynamics and the community structure.
\end{abstract}

Key words: Rotifera; autecology; food limitation; seasonal succession; boreal perch lake; acidification.

Received: June 2017. Accepted: November 2017.

\section{INTRODUCTION}

Pelagic rotifers in North Europe and Northern America are affected to various degrees by anthropogenic acidification processes, which include several abiotic and biotic ecosystem changes (Stenson et al., 1993; Keller et al., 1999; Svensson and Stenson, 2002; Vandysh, 2002; Wærvågen and Nilssen, 2003). The majority of biotic studies in the pelagial of acidified lakes during the last decades has been devoted to pelagic cladocerans, while much less effort has been addressed to pelagic copepods and rotifers. In medium and strongly acidified lakes the major planktonic rotifer species are Kellicottia longispina, Polyarthra spp., Keratella taurocephala, and some more rare species are Keratella cochlearis, Collotheca spp., Ascomorpha spp., and Keratella serrulata (Skadovsky, 1926, 1933; Yan and Geiling, 1985; Bērziņš and Pejler, 1987; Morling and Pejler, 1990; Siegfried, 1991; Svensson and Stenson, 2002; Wærvågen and Nilssen, 2003). Most studies focus on non-acidic lakes (Ruttner, 1930;
Nauwerck, 1963; Larsson, 1971, 1978; Zimmermann, 1974; Makarewicz and Likens, 1975; Armengol-Díaz et al., 1993; Armengol et al., 1998; Bartumeus and Catalan, 2008; Obertegger et al., 2008), while less is known about acidic lakes. Few studies on rotifer community alterations during acidification are published (Roff and Kwiatkowski, 1977; Hobæk and Raddum, 1980; Mac Isaac et al., 1987; Frost et al., 1998), whereas quantitative seasonal and vertical distribution during acidification is less well known.

Individual species of rotifers display different embryonic development times based on food threshold concentrations influencing interspecific competition (Herzig, 1983; Stemberger and Gilbert, 1985, 1987a, 1987b; Walz, 1995), and consequently affect community species composition during acidification (Wærvågen and Nilssen, 2003). Rotifers often have higher threshold food concentrations than many filter-feeding cladocerans (Duncan, 1989), which makes them inferior competitors at lower food abundance levels. Therefore, when cladocerans dominate, raptorial rotifers feed selectively on larger food items (Obertegger et al., 2011). Rotifer community alternations 
are often caused by changes in ecosystem productivity driven by eutrophication or acidification (Duncan, 1989; Walz, 1995; Stelzer, 2005). Rotifers are usually more productive under eutrophic conditions whereas food limitation is more probable under oligotrophic conditions (Walz, 1995). Nutrient-rich environments therefore support much higher rotifer abundance, characterized by rotifer species with smaller egg sizes and faster development (Herzig, 1983; Orcutt and Pace, 1984; Walz, 1993). Most rotifers produce resting eggs with typical egg-bank characteristics (Nipkow, 1961), and are known for their rapid re-appearance after water chemistry recovery following prolonged acidification (Raddum et al., 1986; Svensson and Stenson, 2002; Wærvågen and Nilssen, 2003).

It is crucial for the understanding of anthropogenic lake acidification and possible trajectories of lake recovery to distinguish between several different categories of acidified lakes (Nilssen and Wærvågen, 2002a; Wærvågen and Nilssen, 2003, 2011), especially chronically acidic lakes and so-called acid-transition lakes (Henriksen, 1979, 1980). In chronically acidic lakes, the bicarbonate buffering capacity is inoperative and $\mathrm{pH}$ has stabilised in the low range, usually at 4.4-4.8 (Nilssen, 1982a). Furthermore, all fish species have been eliminated and the new top lake predators are different species of invertebrates, especially pelagic corixids and notonectids (Hemiptera), chaoborids (Diptera), and water beetles (Coleoptera). Acid-transition lakes, including categories between slightly affected and chronically acidified, characterise localities in which the residual bicarbonate buffering capacities are negatively affected with strong $\mathrm{pH}$ fluctuations usually between 5.0 and 6.0. In the boreal part of Fennoscandia such lakes were extremely common during the peak acidification period (Henriksen, 1979, 1980), and many organisms, including most fish species, were negatively affected or disappeared altogether (Nyberg et al., 1995). A typical acid-transition lake is dominated by aging fish populations (in southern Norway often Eurasian perch, aged 5-7 years on average), while young stages are missing or produce strong cohorts only in years with favourable spring climatic conditions (Kleiven et al., 1990; Linløkken et al., 1991). In acidic, fish-deficient or fishless ecosystems, competition and invertebrate predation are probably of decisive importance in rotifer ecology (Eriksson et al., 1980; Nyman et al., 1985; Yan et al., 1991). The susceptibility of rotifers to invertebrate predators is fairly well documented in non-acidic lakes, however, except for the voracious chaoborid larvae, such knowledge is sparse for acidified lakes (Nyberg, 1984; Yan et al., 1991).

Aquatic ecosystems have been studied in this region of southern Norway since the early 1970s, including both the anthropogenic acidification of aquatic systems and their subsequent recovery during recent years (Nilssen, 1980, 1984; Nilssen and Sandøy, 1990; Nilssen and
Wærvågen, 2002a, 2002b, 2003; Wærvågen and Nilssen, $2003,2010,2011)$. The majority of lakes in this area were, at the time of the present study (1980-81), still strongly affected by acid precipitation from a variety of sources in Europe (Drabløs and Tollan, 1980; Nilssen, 1980, 1982a, 1982b). The investigated boreal Lake Gjerstadvann (Fig. 1) belonged to a typical acid-transition lake category with $\mathrm{pH}$ fluctuating between 5.0 and 5.6. The study was part of a research programme in southern Norway (Fig. 1), which comprised lakes with strongly contrasting chemistry and biology. The aim of the present study was to investigate the seasonal and vertical quantitative distribution of pelagic rotifers in order to relate the rotifer community to abiotic and major biotic factors in a typical boreal acidic-transition lake dominated by Eurasian perch. This may improve our general knowledge concerning the process of acidification and ecosystem structures of anthropogenic acidified lakes and their subsequent recovery, including the ecology, life histories and habitat dynamics of pelagic rotifers in northern boreal lakes.

\section{METHODS}

\section{Study area}

Samples from Lake Gjerstadvann were collected from early February 1980 to mid-March 1981 . The lake is situated $31 \mathrm{~m}$ above sea level (asl) $\left(58^{\circ} 53^{\prime} \mathrm{N}, 9^{\circ} 02^{\prime} \mathrm{E}\right.$, WGS84 datum) in a region in southern Norway characterised by a mixture of continental and oceanic climates (Fig. 1 a,b). Lake Gjerstadvann is dimictic with bottom temperatures slightly above $4^{\circ} \mathrm{C}$ in the ice-free period and with a relatively deep mixed layer because of its considerable water through-flow (Figs. 1d and 2). The seasonal changes in water chemistry are mainly due to spring snow-melt and seasonal rainfalls in summer and autumn (Figs. 1d and 2), which are further described in Wærvågen and Nilssen (2010). The lake is situated below the postglacial marine limit (i.e. about $100 \mathrm{~m}$ asl in this area), but most of the catchment area of the lake is situated above the postglacial marine limit, thus draining more acidified water, measured with mean pH 4.7 in 1980 (Hindar et al., 1984). Lake Gjerstadvann had a mean $\mathrm{pH}$ of 5.2 in 198081, was oligotrophic (based on total phosphorus; see Results), and oligo- to mesohumic (based on the water colour in $\mathrm{mg} \mathrm{Pt} \mathrm{L}^{-1}$; see Fig. 2). Mean reactive aluminium (RAl) concentrations were $200-250 \mu \mathrm{g} \mathrm{L}^{-1}$, and the harmful labile fraction (1Al) at these $\mathrm{pH}$ values was about 40$70 \%$ of the RAl values (Lydersen, 1998).

\section{Sampling and data collection}

Chemical and biological samples were taken simultaneously, approximately at mid-day, every fortnight during the ice-free period, and circa monthly during the rest of 
the year. Chemical samples were collected using a Ruttner sampler at a fixed station at the deepest point $(27 \mathrm{~m})$ of the lake (Fig. 1c), at depths shown in Tab. 1. Water colour expressed as $\mathrm{mg} \mathrm{Pt} \mathrm{L}^{-1}$ was measured on a Lovibond comparator, primarily representing the amount of aquatic humic substances (Fig. 2). Total organic carbon (TOC) content of the water is closely related to $\mathrm{Pt}\left(\mathrm{mg} \mathrm{L}^{-1}\right)$, and usually TOC corresponds to one-tenth of the Pt-value in this North European Fennoscandian region (Degerman, 1987). Chemical analyses were performed according to standard analytical methods, see further details in Wærvågen and Nilssen (2010). a)
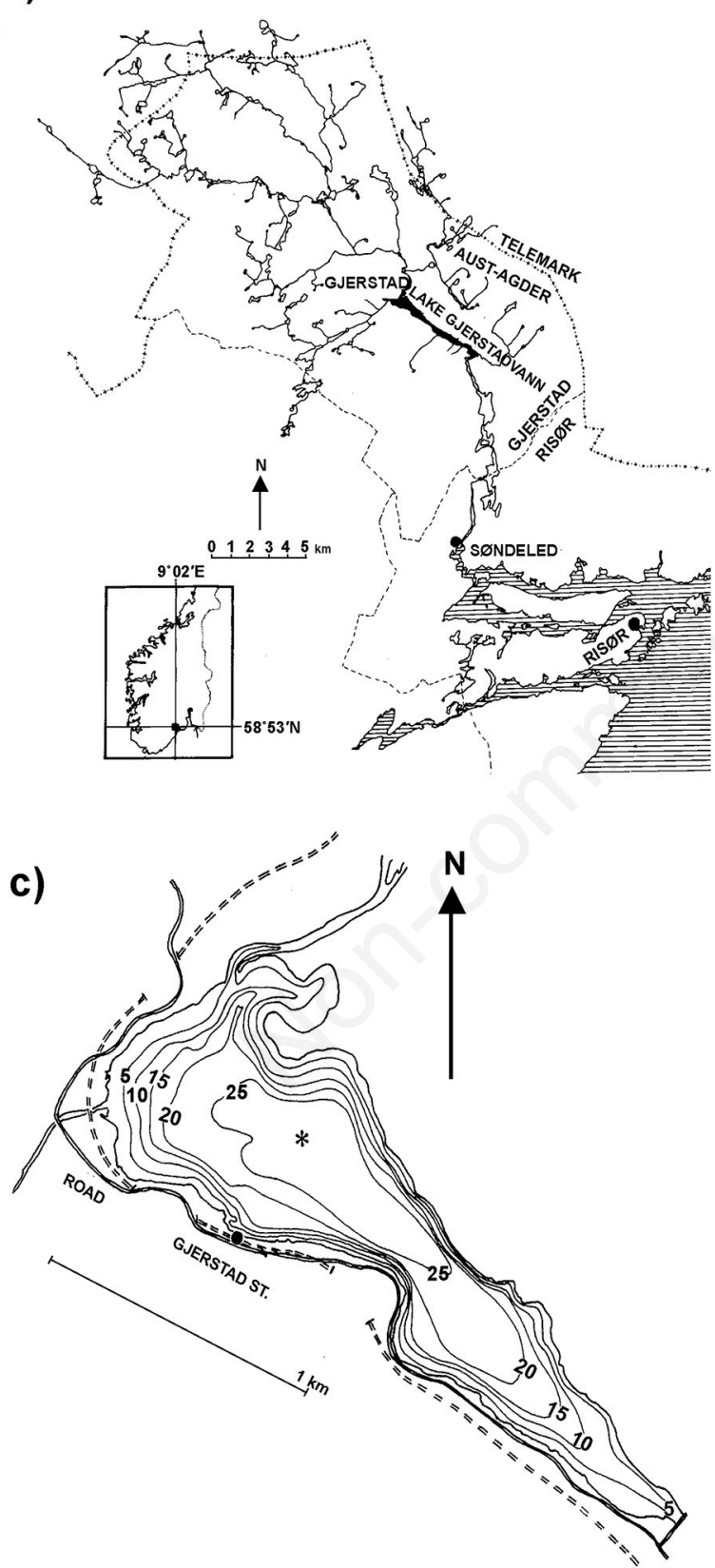

b) Air Temperature

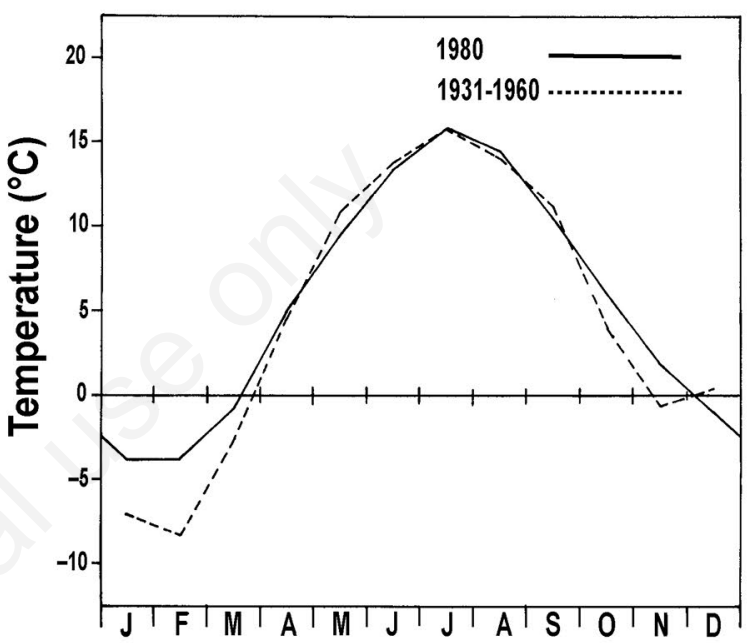

d) Specific discharge

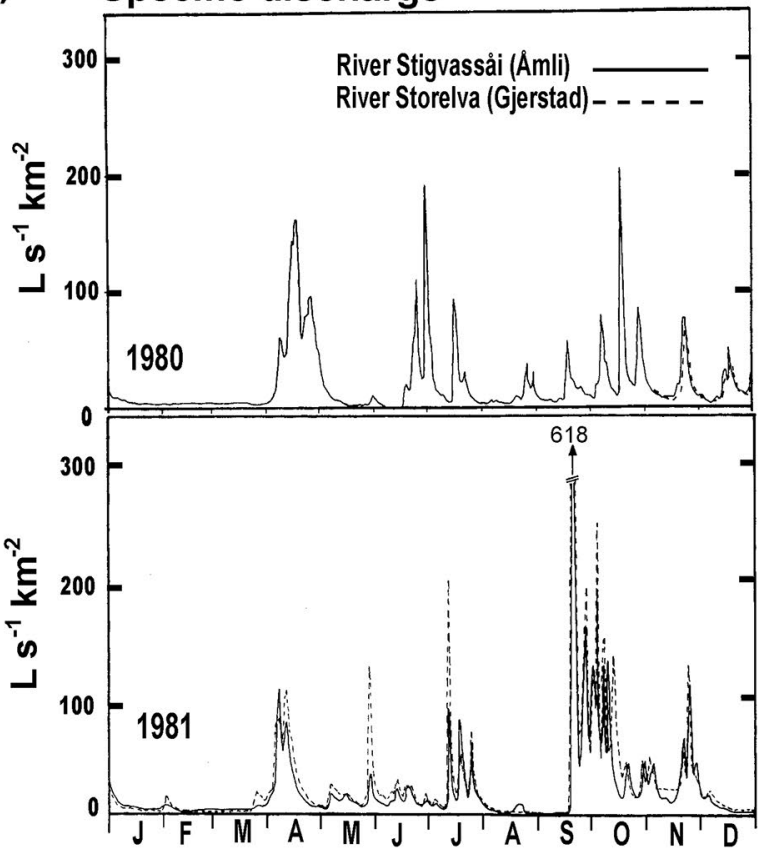

Fig. 1. Lake Gjerstadvann and its catchment area. a) Geographical position in southern Norway; b) catchment area climate (as mean monthly air temperature); c) depth map with sampling station (*); d) streamflow as specific discharge $\left(\mathrm{L} \mathrm{s}^{-1} \mathrm{~km}^{-2}\right)$ of the dominating inlet River Storelva (---------, no available data before November 1980) and a neighbouring, continuously monitored River Stigvassåi (—, used as a proxy for River Storelva in 1980). 
Duplicate quantitative zooplankton samples were collected in Lake Gjerstadvann using a 15 litre Patalas/Schindler device (Schindler, 1969), with an attached net with mesh size $45 \mu \mathrm{m}$. The volume proportions (Tab. 1) were calculated from a volumetric curve used to convert the total and mean population abundance at different depths of all species to individuals per $\mathrm{m}^{3}$
(Bottrell et al., 1976). Most metazoan zooplankton (Tab. 2) were identified to species level and counted (Rylov, 1963; Flößner, 1972; Ruttner-Kolisko, 1972; Einsle, 1975; Kiefer, 1978). Preserved with Lugol's solution, identification was primarily based on morphological characteristics included the lorica, foot, and anterior projections (Ruttner-Kolisko, 1972; Koste and Voigt, 1978; Pontin,

Tab. 1. Sampling depths of chemical and quantitative zooplankton samples in Lake Gjerstadvann 1980/81. The representative layers given in $\%$ and volume proportions.

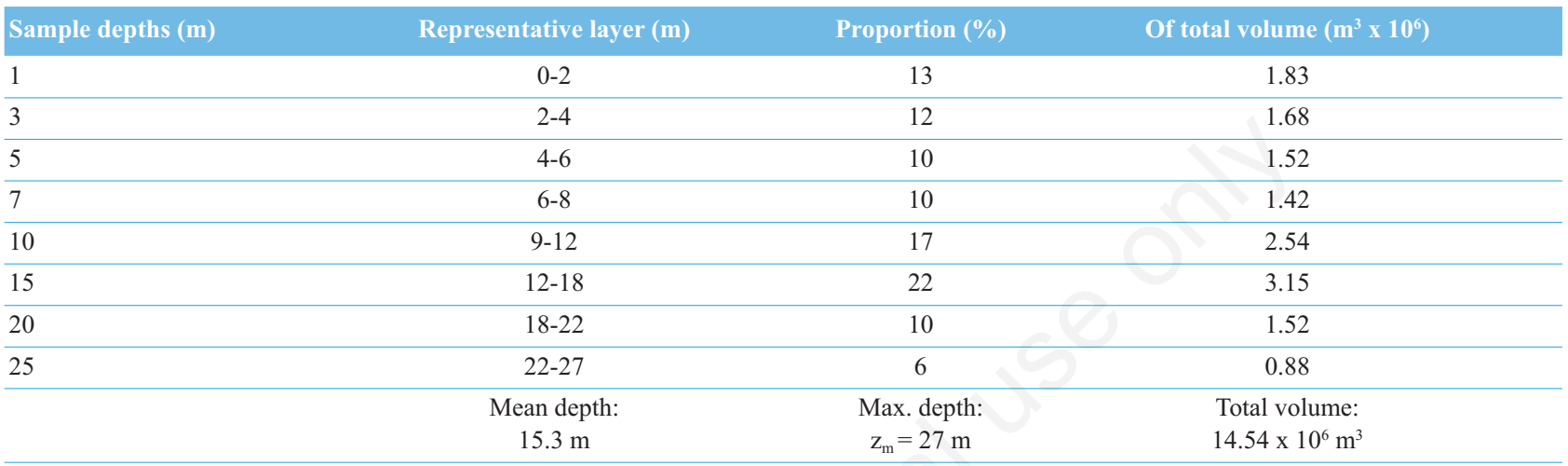
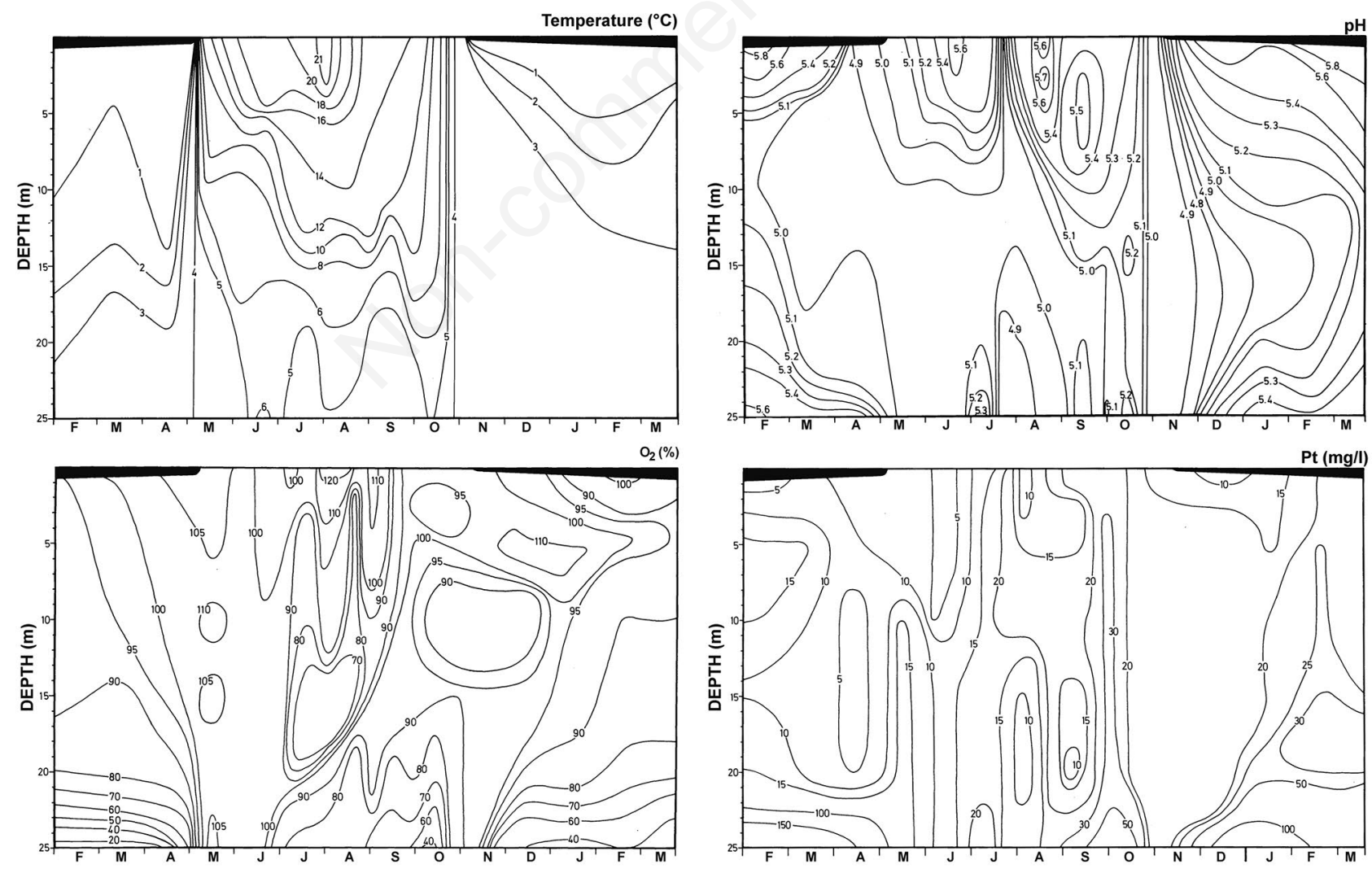

Fig. 2. Isoplots for temperature $\left({ }^{\circ} \mathrm{C}\right), \mathrm{pH}$, oxygen $(\%)$ and water colour Pt $\left(\mathrm{mg} \mathrm{L}^{-1}\right)$ in Lake Gjerstadvann 1980-1981. Ice covers are shown in real dimensions as black bars here and in similar figures. 
1978; Nogrady et al., 1993). Due to Lugol's-induced retraction, especially within the genera Conochilus, Synchaeta, Polyarthra and Ascomorpha, body size measurements were, in addition, performed under the microscope. Rotifers can be categorized as suspension feeders (Keratella spp., K. longispina, Conochilus spp.), raptorial graspers or specialised feeders (Polyarthra spp., Synchata spp., Ascomorpha spp., Collotheca spp.), and carnivorous/omnivorous species (Asplanchna spp., Ploesoma spp.) (Nogrady et al., 1993; Walz, 1995, 1997; Obertegger et al., 2011). Cladocerans, copepods, and fish species present in Lake Gjerstadvann are presented in Tab. 2.

\section{Statistical analyses}

Rotifer community structure was investigated by nonmetric multidimensional scaling ordination (NMDS;
Minchin, 1987) using a Bray-Curtis dissimilarity measure calculated from fourth root-transformed rotifer abundances and the metaMDS function in the vegan package (Oksanen et al., 2013). We excluded one sample, where no rotifers were detected, from the analysis. We also excluded two rotifer species (Asplanchna priodonta and Keratella ticinensis) with low occurrence (less than 20\% of the samples). Relationships between rotifer community ordination axes and explanatory variables were investigated by permutation tests using the envfit function of the vegan package. The first two axes of a principal component analysis (PCA) of scaled and centered environmental variables explained $58 \%$ of the total variance. Based on the PCA biplot (Fig. 3) we chose temperature, oxygen, $\mathrm{pH}$, and reactive aluminum ( $\mathrm{RAl})$ to represent the major environmental gradients. The first two represented the major seasonal and vertical gradients in the lake, while the latter two served as acidification indicators. We rep-

Tab. 2. List of all metazoan species collected in the pelagial of Lake Gjerstadvann in 1980/81.

\begin{tabular}{|c|c|c|c|}
\hline \multicolumn{2}{|l|}{ Rotifera } & \multicolumn{2}{|l|}{ Cladocera } \\
\hline Conochilus unicornis Rousselet, 1892 & XXX & Bosmina longispina Leydig, 1860 & $\mathrm{XXX}$ \\
\hline Conochilus hippocrepis (Schrank, 1803) & $\mathrm{R}$ & Holopedium gibberum Zaddach, 1855 & $\mathrm{XX}$ \\
\hline Polyarthra minor Voigt, 1904 & XXX & Diaphanosoma brachyurum (Liéven, 1848) & XXXX \\
\hline Polyarthra vulgaris Carlin, 1943 & $\mathrm{XX}$ & Polyphemus pediculus (Linnaeus, 1761) & $\mathrm{X}$ \\
\hline Polyarthra dolichoptera Idelson, 1925 & $\mathrm{R}$ & Bythotrepes longimanus Leydig, 1860 & $\mathrm{X}$ \\
\hline Kellicottia longispina (Kellicott, 1879) & XXX & Ceriodaphnia quadrangula (O.F. Müller, 1776) & $\mathrm{X}$ \\
\hline Keratella hiemalis Carlin, 1943 & $\mathrm{XX}$ & Leptodora kindti (Focke, 1844) & $\mathrm{X}$ \\
\hline Keratella cochlearis (Gosse, 1851) & $\mathrm{XX}$ & Chydoridae spp. Stebbing, 1902 & $\mathrm{X}$ \\
\hline Keratella serrulata (Ehrenberg, 1838) & $\mathrm{X}$ & Scapholeberis mucronata (O.F. Müller, 1776) & $\mathrm{R}$ \\
\hline Keratella ticinensis (Callerrio, 1920) & $\mathrm{X}$ & Sida crystallina (O.F. Müller, 1776) & $\mathrm{R}$ \\
\hline Keratella testudo (Ehrenberg, 1832) & $\mathrm{R}$ & Daphnia lacustris G.O. Sars, 1862 & $\mathrm{R}$ \\
\hline Collotheca libera (Zacharias, 1894) & $\mathrm{X}$ & & \\
\hline Collotheca liepetterseni Bērzin̦š, 1951 & $\mathrm{X}$ & & \\
\hline Ascomorpha ecaudis Perty, 1850 & $\mathrm{X}$ & Insecta & \\
\hline Lecane spp. Nitzsch, 1827 & $\mathrm{X}$ & Chaoborus flavicans (Meigen, 1830) & $\mathrm{X}$ \\
\hline Asplanchna priodonta Gosse, 1850 & $\mathrm{X}$ & & \\
\hline Synchaeta gr. tremula-oblonga & $\mathrm{X}$ & & \\
\hline Euchlanis dilatata Ehrenberg, 1830 & $\mathrm{R}$ & Copepoda & \\
\hline Trichocerca spp. Lamarck, 1801 & $\mathrm{R}$ & Eudiaptomus gracilis (G.O. Sars, 1863) & $\mathrm{XXX}$ \\
\hline Gastropus stylifer Imhof, 1891 & $\mathrm{R}$ & Heterocope saliens (Lilljeborg, 1863) & $\mathrm{R}$ \\
\hline \multirow[t]{3}{*}{ Gastropus minor (Rousselet, 1892) } & $\mathrm{R}$ & & \\
\hline & & Cyclops scutifer G.O. Sars, 1863 & XXX \\
\hline & & Mesocyclops leuckarti (Claus, 1857) & $\mathrm{XX}$ \\
\hline Fish & & Thermocyclops oithonoides (G.O. Sars, 1863) & $\mathrm{X}$ \\
\hline Perca fluviatilis Linnaeus, 1758 & XXX & Cyclops abyssorum G.O. Sars, 1863 & $\mathrm{R}$ \\
\hline Salmo trutta Linnaeus, 1758 & $\mathrm{XX}$ & Diacyclops nanus (G.O. Sars, 1863) & $\mathrm{R}$ \\
\hline Coregonus lavaretus (Linnaeus, 1758) & $\mathrm{X}$ & Diacyclops bicuspidatus (Claus, 1857) & $\mathrm{R}$ \\
\hline Salvelinus alpinus (Linnaeus, 1758) & $\mathrm{R}$ & Megacyclops gigas (Claus, 1857) & $\mathrm{R}$ \\
\hline
\end{tabular}

Relative abundance within each group of animals: $X X X$, dominating; $X X$, frequent; $X$, few specimens; $R$, rare. 
resented a second group of biotic explanatory variables as the fourth root-transformed abundances of two potential predators, Chaoborus flavicans (see C. flavicans in Fig. 4) and "Cyclopoids" (the sum of Cop IV-adult stages of all cyclopoid copepods) (Fig. 4 and Tab. 2). Furthermore, we included two potential competitors, Bosmina longispina and Eudiaptomus gracilis (as the sum of all its stages). Finally, we used the varpart function of vegan (Borcard et al., 1992) to identify fractions of total redundancy analysis variance that could be explained uniquely by either environmental gradients or biotic interactions.

\section{RESULTS}

The annual mean $\mathrm{pH}$ in Lake Gjerstadvann was 5.2, but dropped slightly below this value during the spring ice breakup and autumn and summer rain periods (Figs. 1d and 2). The epilimnetic oxygen content fluctuated around 100 percent during most of the year, with an oxygen deficit close to the lake bottom during periods of stagnation (Fig. 2), most probably due to accumulation of allochthonous organic material. The epilimnetic colour of the lake water was $10-30 \mathrm{mg} \mathrm{Pt} \mathrm{L} \mathrm{P}^{-1}\left(\approx 1-3 \mathrm{mg}\right.$ TOC L $\left.\mathrm{L}^{-1}\right)$, and increased considerably $\left(\approx 10-15 \mathrm{mg} \mathrm{TOC} \mathrm{L}^{-1}\right)$ above the bottom sediments (Fig. 2). The close correlation between $\mathrm{Pt}$ and iron $(\mathrm{Fe})$ in Fig. 3 indicates Fe-colour contribution to TOC under oxygen deficit close to the bottom. In 198081, the following mean concentrations were recorded: ca. $2.0 \mathrm{mg} \mathrm{L}^{-1} \mathrm{Ca}^{2+}, 8 \mu \mathrm{g} \mathrm{L}^{-1}$ total phosphorus (TP), $6 \mathrm{mg} \mathrm{L}^{-1}$ sulphate, $2.2 \mathrm{mg} \mathrm{L}^{-1}$ chloride, and $230 \mu \mathrm{g} \mathrm{L}^{-1}$ reactive aluminium (RAl); specific conductivity, expressed as $\mathrm{K}_{25}$, was

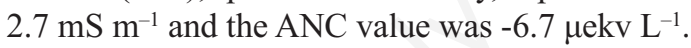

The converged NMDS ordination had relatively high

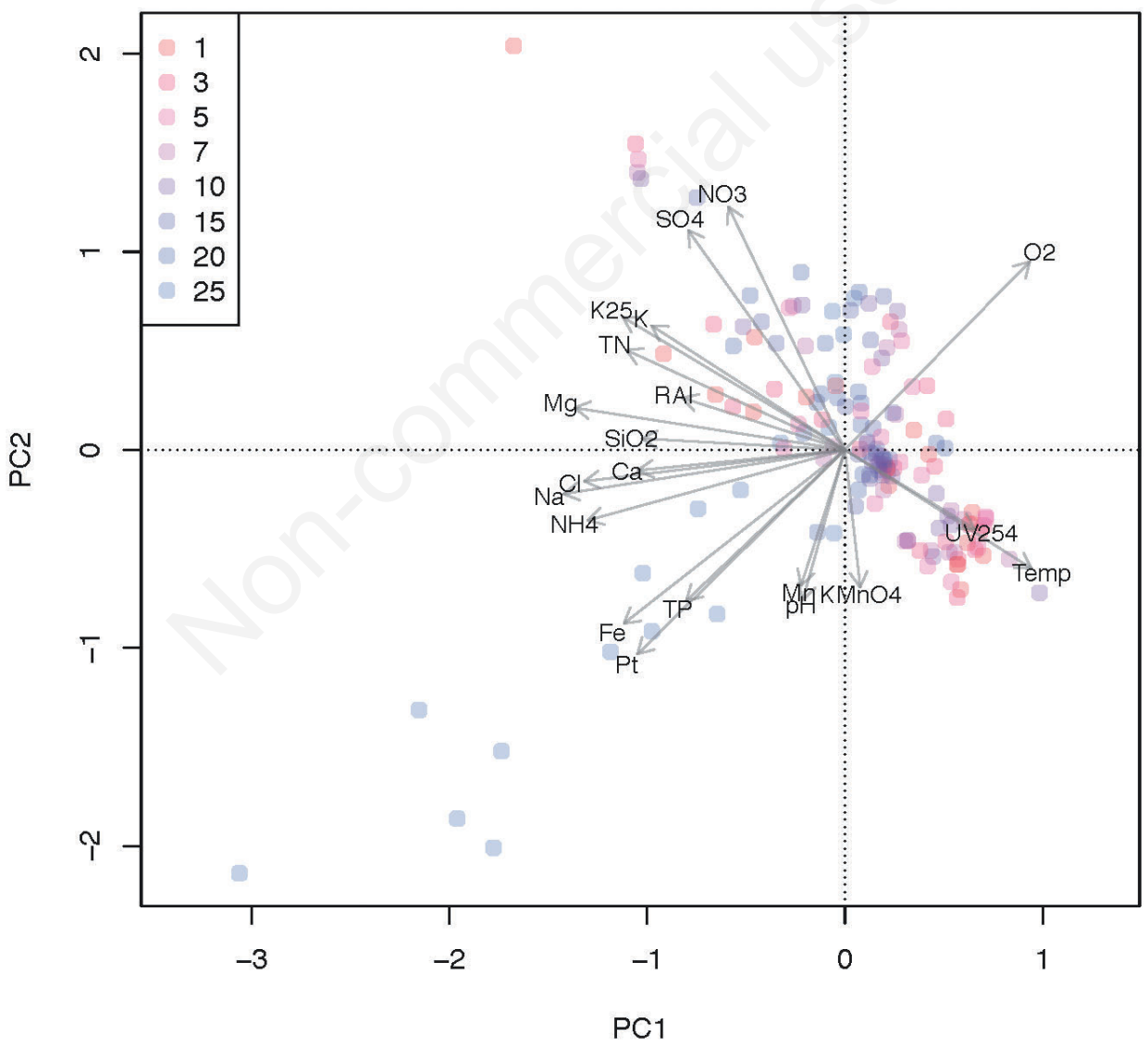

Fig. 3. Principal Components biplot of physical and chemical water quality parameters, based on variables that have been centred and scaled to zero means and unit standard deviations. Arrows represent loadings of the different parameters while dots represent scores of individual samples, colour coded according to sample depth (see top left in this Fig. and Tab. 1). PC1 and PC2 represented 39\% and $19 \%$ of the total variance, respectively. Key to environmental parameters: Temp (temperature), O2 (\% oxygen), pH, K25 (conductivity as $K_{25}$ ), RAl (reactive aluminium), TN and TP (total $\mathrm{N}$ and $\mathrm{P}$ ), Fe and $\mathrm{Mn}$ (total Fe and $\mathrm{Mn}$ ), $\mathrm{SiO} 2\left(\mathrm{SiO}_{2}\right), \mathrm{UV}^{254}$ (organic matter as $\mathrm{UV}$-absorption at $254 \mathrm{~nm}$ ), $\mathrm{KMnO} 4$ (organic matter determined by oxidation with $\mathrm{KMnO}_{4}$ ), $\mathrm{Pt}$ (water colour expressed as mg Pt $\mathrm{L}^{-1}$, closely related to TOC) and finally the ions $\mathrm{Ca}\left(\mathrm{Ca}^{2+}\right), \mathrm{Mg}\left(\mathrm{Mg}^{2+}\right), \mathrm{Na}\left(\mathrm{Na}^{+}\right), \mathrm{K}\left(\mathrm{K}^{+}\right), \mathrm{SO} 4\left(\mathrm{SO}_{4}{ }^{2-}\right), \mathrm{Cl}\left(\mathrm{Cl}^{-}\right), \mathrm{NO}\left(\mathrm{NO}_{3}{ }^{-}\right), \mathrm{NH}^{2}\left(\mathrm{NH}_{4}^{+}\right)$. 
stress (0.22) for 2 axes. Including 3 or 4 axes reduced the stress to 0.15 and 0.10 , respectively, but Procrustes tests showed that all solutions were very similar in the first 2 axes (vegan protest function, all with $\mathrm{P}=0.001$ on 999 permutations). The NMDS ordination diagram (Fig. 4) appears to capture the seasonal cycle with Collotheca liepetterseni and Keratella hiemalis as winter species, being replaced by K. longispina, Polyarthra spp., Conochilus unicornis and Lecane spp. in summer (June-August). Ascomorpha ecaudis and Synchaeta gr. tremula-oblonga have higher abundances in spring and late summer/autumn, while $K$. cochlearis is characteristic of the autumn/winter transition. The least common species included in the analysis, $K$. serrulata seemed to have no distinct environmental or seasonal preferences. The explanatory variables fitted to the ordination are represented by grey arrows in Fig. 4. Among the environmental gradient indicators there were significant ef- fects of temperature and oxygen $(\mathrm{P}=0.001$ and $\mathrm{P}=0.022)$, but not of the acidification indicators ( $\mathrm{pH}$ and $\mathrm{RAl}$ : $\mathrm{P}=0.214$ and $\mathrm{P}=0.156$, respectively). Among the biotic variables, none of the predation indicators were significant ( $\mathrm{P}=0.410$ and $\mathrm{P}=0.493$ for $C$. flavicans and "Cyclopoids", respectively), while both the competition indicators $B$. longispina and E. gracilis were highly significant (both with $\mathrm{P}=0.001$ ). Temperature, which had the highest correlation to the ordination axes among the environmental variables, was mainly associated with the first NMDS axis, while oxygen had stronger associations with the second NMDS axis. The highly significant competition indicators (B. longispina and E. gracilis) were also mainly associated with first NMDS axis. A variance partitioning sensu Borcard et al. (1992) indicated that biotic interactions could explain $14 \%$ of the total community variance uniquely, while $19 \%$ of the variance could be attributed to environ-

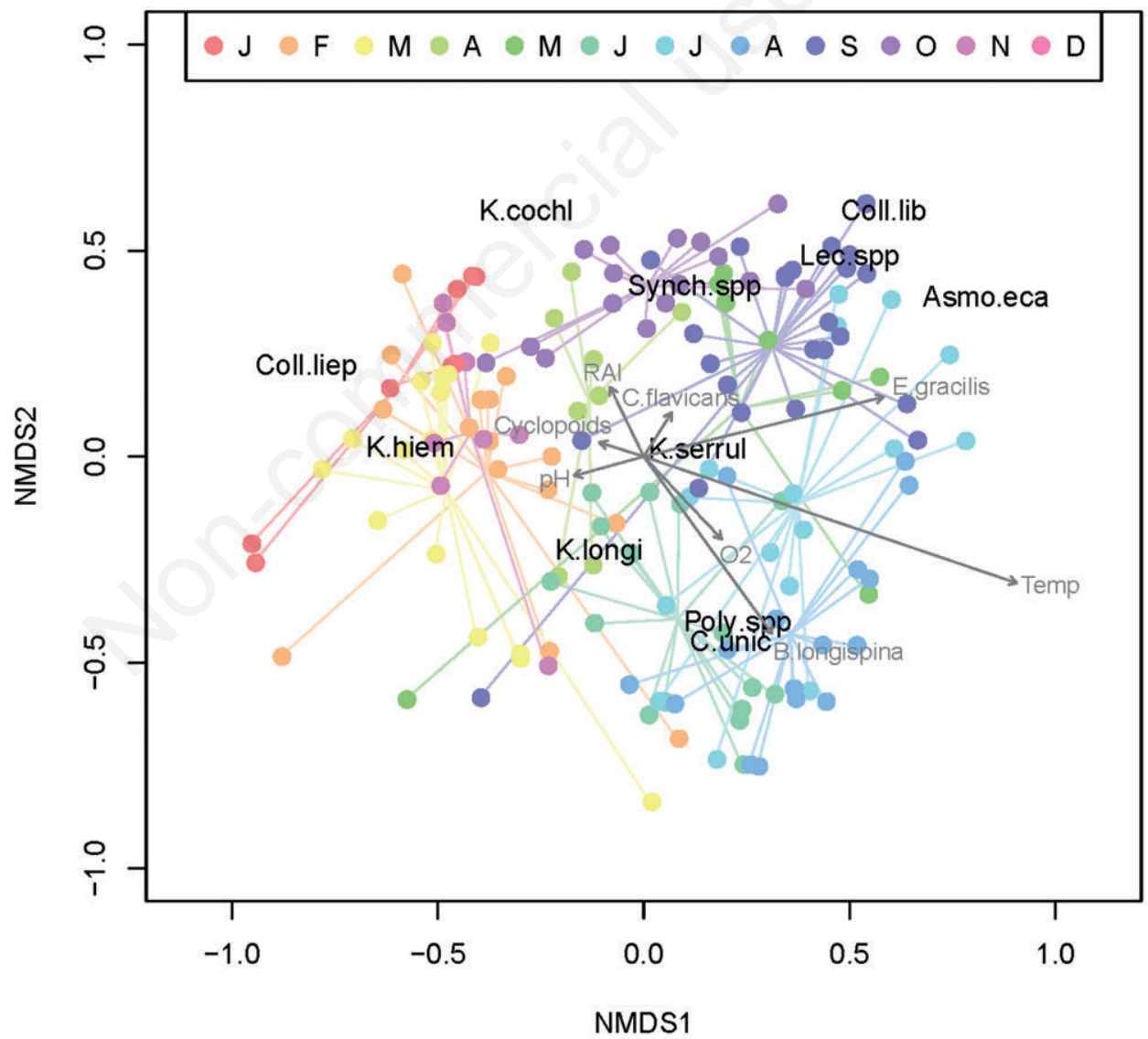

Fig. 4. NMDS ordination diagram based on Bray-Curtis dissimilarity of fourth root-transformed rotifer abundances, showing species loadings using the abbreviations below and with fitted environmental gradients and biotic interactions indicated by grey arrows. Sample scores are colour coded by month and indicated by thin lines from individual score points to the monthly centroid. The potential predators shown as C. flavicans (larvae) and Cyclopoids (see Methods), and finally the two potential competitors E. gracilis and B. longispina. Key to rotifer species: C.unic (Conochilus unicornis), Poly.spp (Polyarthra spp.), K.longi (Kellicottia longispina), K.hiem (Keratella hiemalis), K.cochl (Keratella cochlearis), K.serrul (Keratella serrulata), Coll.liep (Collotheca liepetterseni), Coll.lib (Collotheca libera), Asmo.eca (Ascomorpha ecaudis), Lec.spp (Lecane spp.), Synch.spp (Synchaeta gr. tremula-oblonga). 
mental gradients. Twenty-three percent of the variance could not be resolved between biotic interactions and environmental gradients, while a residual of $44 \%$ could not be explained by any of the variables.

The majority of the Conochilus population in Lake Gjerstadvann was identified as C. unicornis, with some very few Conochilus hippocrepis specimens in addition. The colonial C. unicornis was most abundant in the upper water masses during summer (slightly above 100 ind. $\mathrm{L}^{-1}$ ), but was also present under ice cover (Fig. 5a). The other species, C. hippocrepis was recorded in small numbers at all depths in the autumn overturn, but was not found during the spring overturn (Fig. 5a). Polyarthra spp. also displayed the largest population abundance during the icefree period (close to 50 ind. $\mathrm{L}^{-1}$ ), and much lower during winter (Fig. 5b). The most abundant species were Polyarthra minor and Polyarthra vulgaris, whereas Polyarthra dolichoptera was recorded in small numbers in the upper water masses during late autumn/early winter. The individual Polyarthra species relative to seasonal and vertical abundance are indicated in Fig. 5b, where P. minor was the predominant summer species and $P$. vulgaris was prevalent during the rest of the year.

The only typical perennial species recorded was $K$. longispina, showing distribution at all depths (Fig. 6a). Mean abundance of this species was lowest during winter with about 2-4 ind. $\mathrm{L}^{-1}$, and it displayed two population peaks during early summer and early autumn at 8 and 10 ind. $\mathrm{L}^{-1}$, respectively (Fig. 6a). The highest abundance approached 50 ind. $\mathrm{L}^{-1}$ in summer epilimnion and close to metalimnion during early autumn. Egg production took place at most water depths during the ice-free period, and at deeper water layers during the period with ice cover (Fig. 6a).

The typical cold-water species, Keratella hiemalis, displayed autumn and winter population peaks (Fig. 6b). Its abundance peaked close to the sediment with maximum mean abundance of about 1 ind. $\mathrm{L}^{-1}$ and with an absolute maximum of 20 ind. $\mathrm{L}^{-1}$ during February 1980 . Keratella hiemalis carried eggs at depths close to the sediment surface during most of the year. Keratella cochlearis had relatively low abundance in Lake Gjerstadvann, with a maximum mean slightly above 1 ind. $\mathrm{L}^{-1}$ (Fig. 6c). It displayed population peaks in the deeper parts of the lake later than the periods of maximum abundance for most other rotifer species. It also produced eggs in that period of the year, whereas winter reproduction was almost absent.

Collotheca libera occurred in all water masses in a very restricted period during autumn (Fig. 6d), with a mean abundance of about 3 ind. $\mathrm{L}^{-1}$, whereas $C$. liepetterseni showed maximum abundance during late winter and spring (Fig. 6d). Ascomorpha ecaudis (Fig. 6e) and the genus Lecane spp. (Fig. 6f) both showed three separate peaks during the ice-free period, with maximum mean abundance of 0.2 and 0.6 ind. $\mathrm{L}^{-1}$, respectively. The Lecane spp. were identified as Lecane mira, L. bulla, $L$. lunaris, L. scutata and L. closterocerca.

Some of the rotifer species with least abundance are summarised in Fig. 7. Keratella serrulata was nearly perennial while $K$. ticinensis showed autumn and winter population peaks, both were recorded close to the sediment surface. Population maxima for Synchaeta gr. tremula-oblonga occurred in summer and winter/spring, but also with minor perennial presence. Population numbers of the carnivorous/omnivorous species $A$. priodonta peaked in a restricted period during autumn with a mean abundance of about 0.3 ind. $\mathrm{L}^{-1}$. The most abundant rotifer species in Lake Gjerstadvann are shown together with major ecological factors such as temperature and food; algae (usually well below $200 \mathrm{~mm}^{3} \mathrm{~m}^{-3}$ ) and organic matter were calculated as TOC in $\mathrm{mg} \mathrm{L}^{-1}$ (Fig. 8).
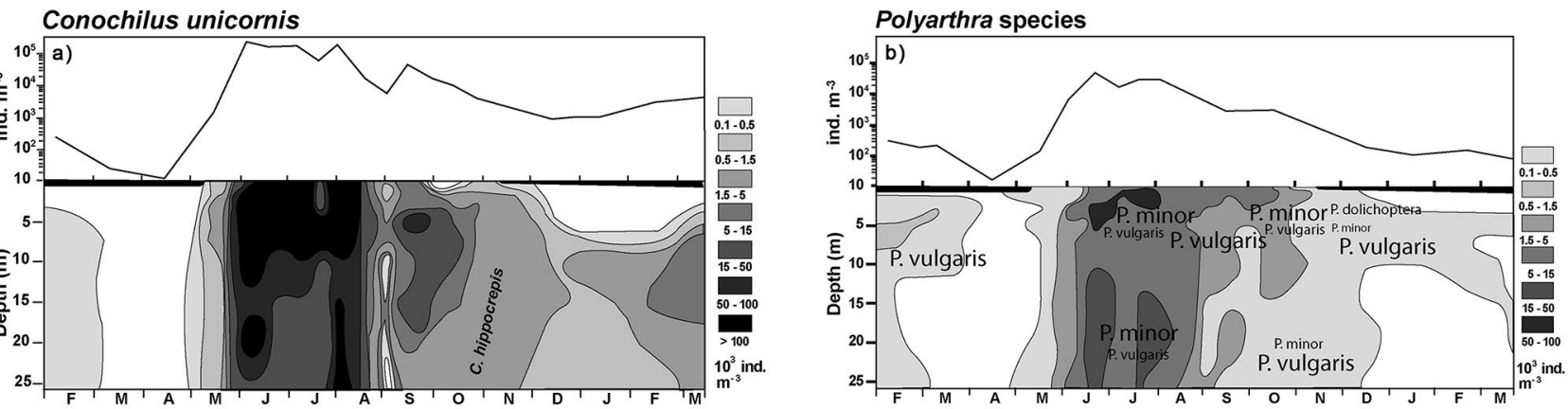

Fig. 5. Population abundance (logaritmic scale) and vertical distribution of the two most abundant rotifer species in Lake Gjerstadvann during 1980/1981. a) Conochilus unicornis and some few specimens of Conochilus hippocrepis recorded at all depths in the autumn overturn (marked in the graph); b) Polyarthra spp., where Polyarthra vulgaris was the most abundant species during late summer epilimnion, early autumn, and the whole winter, whereas Polyarthra minor dominates most of the summer season. Polyarthra dolichoptera was recorded in small numbers in the upper water masses during late autumn/early winter. The font sizes indicate the individual species abundance. 


\section{DISCUSSION}

Lake Gjerstadvann forms part of an investigated region of small lakes with a variety of pelagic fish, invertebrate predation and acidification (Nilssen, 1980, 1984; Fjerdingstad and Nilssen, 1982). Many are oligotrophic perch-lakes (Demmo, 1985; Næss, 1985), such as Lake Gjerstadvann (Linløkken, 1985, 1988), but also meso- and
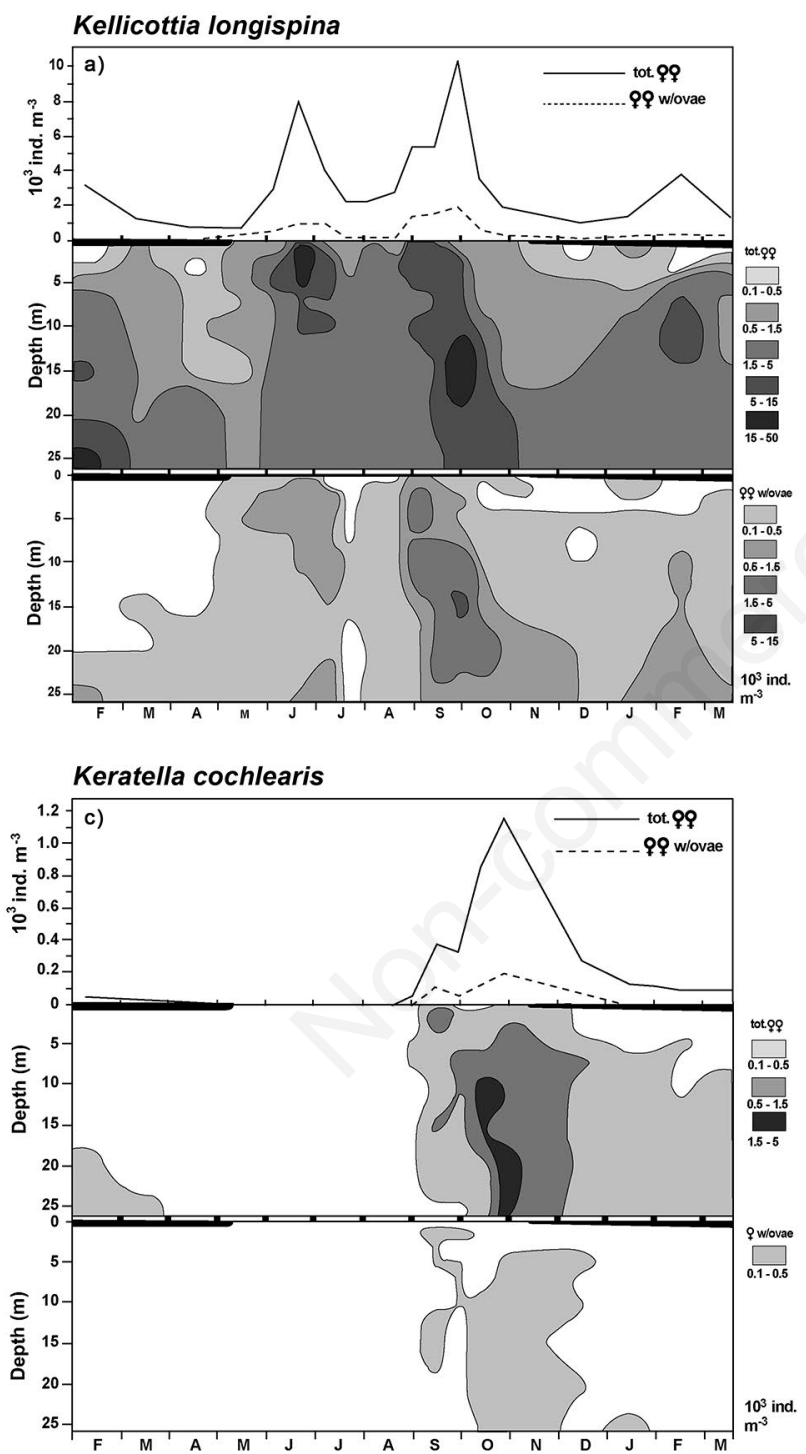

eutrophic lakes with low fish predation dominated by large-sized Daphnia spp. (Larsen, 1982; Nilssen and Wærvågen, 2002a; Wærvågen and Nilssen, 2003). A small group of strongly acidified, fishless lakes have communities dominated by pelagic rotifers during the whole year (Sandøy, 1984), probably a consequence of intensive predation of Chaoborus spp. larvae on crustaceans (Nyberg, 1984). Rotifers are normally controlled by a combination of factors: the physiological relationship to
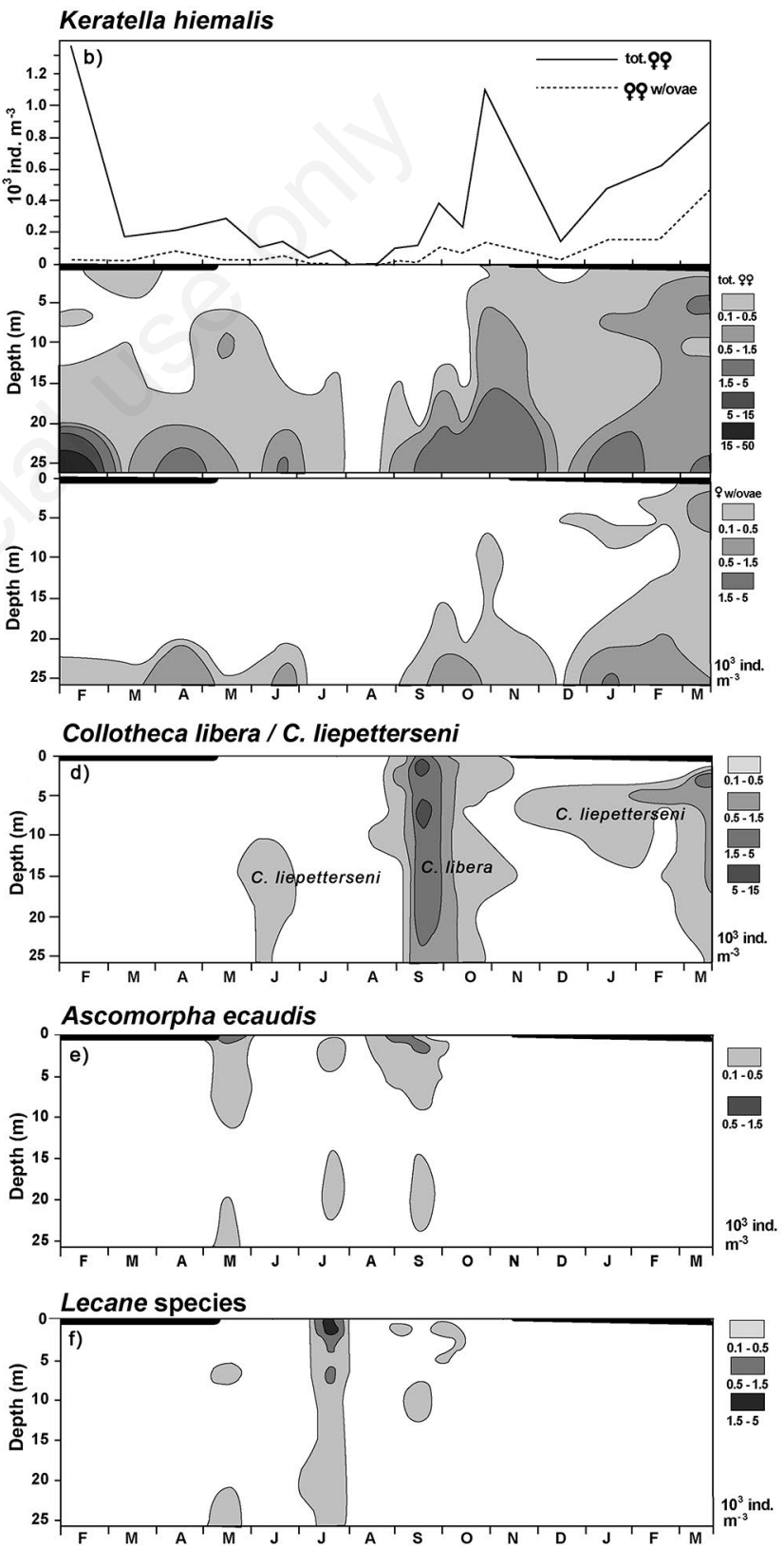

Fig. 6. Population abundance and vertical distribution of the medium abundant rotifer species in Lake Gjerstadvann during 1980/1981. a) Kellicottia longispina; b) Keratella hiemalis; c) Keratella cochlearis; d) Collotheca libera and C. liepetterseni; e) Ascomorpha ecaudis; f) Lecane species (see text for the different Lecane spp.). 
their ambient environment, available food (bottom-up), invertebrate and vertebrate predation (top-down), and interspecific competition with cladocerans (especially largesized Daphnia spp.), herbivorous stages of copepods (such as E. gracilis), as well as between rotifer species (Herzig, 1987; Gonzalez and Frost, 1992; Arndt, 1993; Kirk, 1997a, 1997b; Brandl, 2005; Sarma et al., 2005).

Rotifers are commonly sub-divided into assemblages and species groups related to their quantitative and vertical distribution, where season, temperature and oxygen are important factors (Carlin, 1943; Larsson, 1971; Zimmermann, 1974; Elliott, 1977; Hofmann, 1987; Mikschi, 1989). Usually, perennial epilimnetic forms are considered eurytherms, while perennial hypolimnetic forms and summer-surface forms are mainly viewed as cold-stenotherms and warm-stenotherms, respectively (Larsson, 1971). The above classifications are often helpful, but seasonal and vertical distributions of rotifers may also be strongly influenced by hatching events in the benthic egg-bank (Nipkow, 1961; Sandøy, 1984; Herzig, 1987), as indicated by e.g. Ascomorpha, Synchaeta, Collotheca and Asplanchna in the present study. Thus, the same species can show contrasting seasonal and vertical distributions between neighbouring lakes, and even between years in the same lake (Elliott, 1977; Larsen, 1982; Synnes, 1982; Sandøy, 1984;
Herzig, 1987). As in many other studies, we found the majority of $K$. cochlearis in the deeper lake regions (Demmo, 1985; Næss, 1985; Hofmann, 1987). Further, we found $K$. hiemalis and P. dolichoptera to be coldwater species, the latter also having been thusly characterised by Bērzinšs (1976). Stenson (1983) found that $P$. vulgaris replaced $P$. dolichoptera following an interplay of available food when fish were eliminated from the system. In the oxygen-depleted zone close to the sediments of Lake Gjerstadvann, a zone which often contains high abundance of detritus-associated bacteria (Hessen, 1998), we found high abundances of Conochilus, Polyarthra, and most Keratella species.

\section{Rotifer species response to physiological factors}

Lake Gjerstadvann was a typical acid-transition lake with low $\mathrm{pH}$ and high concentration of toxic aluminium species especially during spring, but with $\mathrm{pH}$ increasing to above 5.5 in the upper water masses during summer periods with less acid rain. We found no significant effects of the acidification indicators $\mathrm{pH}$ and $\mathrm{RAl}$ on the total rotifer community, even though some individual species may be affected. Lake Gjerstadvann was oligo- to mesohumic, which may be a possible reason for the lack of such acidification response, since humus is known to de-

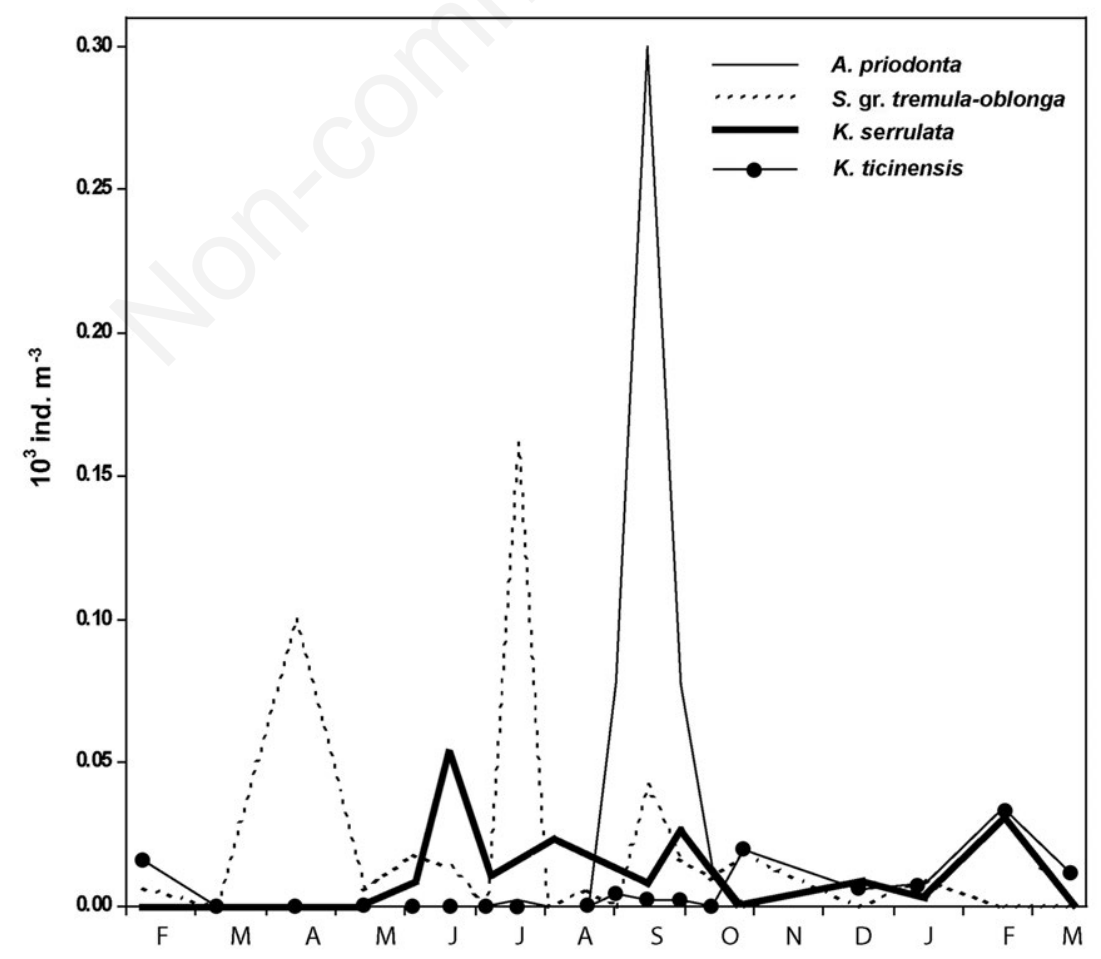

Fig. 7. Population abundance of the less abundant species: Asplanchna priodonta, Synchaeta gr. tremula-oblonga, Keratella serrulata and Keratella ticinensis in Lake Gjerstadvann during 1980/1981. 
toxify poisonous heavy metals and $\mathrm{Al}$ in acidic lakes (Degerman, 1987; Lydersen, 1998). The strong relationship between rotifer community ordination axes and temperature and oxygen illustrates the important effects of seasons and vertical stratification. Rotifer assemblages in Lake Gjerstadvann were similar to communities of other acid-transition lakes in southern Norway (Hobæk and Raddum, 1980; Wærvågen and Nilssen, 2003), with no or few carnivorous/omnivorous species of rotifers such as $A$. priodonta and Ploesoma hudsoni. Correspondingly, no omnivorous species of rotifers were found in the strongly acidified Lake Gårdsjön in Sweden, but were observed in larger numbers following aquatic recovery (Svensson and Stenson, 2002). Few studies, mostly in situ, have been devoted to the physiological tolerance of rotifers against changes in water chemistry (Havens and De Costa, 1988;
Havens and Heath, 1989; Keller et al., 1992), so many questions are still to be answered.

Conochilus unicornis was the most abundant rotifer species in Lake Gjerstadvann. The species is usually absent in chronically acidified lakes (Almer et al., 1974; Holopainen, 1992; Wærvågen and Nilssen, 2003), and rarely observed in high abundance below a $\mathrm{pH}$ of 5.0-5.2 in other acidic regions (Roff and Kwiatkowski, 1977; Havens and De Costa, 1988; Marmorek and Korman, 1993). Conochilus hippocrepis was a minor species in Lake Gjerstadvann, but was abundant in many other acidtransition lakes with $\mathrm{pH}$ below 5.0-5.2 in this region (Nilssen and Wærvågen, 2001). The two closely related species probably display slightly contrasting relationships to their ambient environment, and may serve as a good niche differentiation indicator genus (Wærvågen and

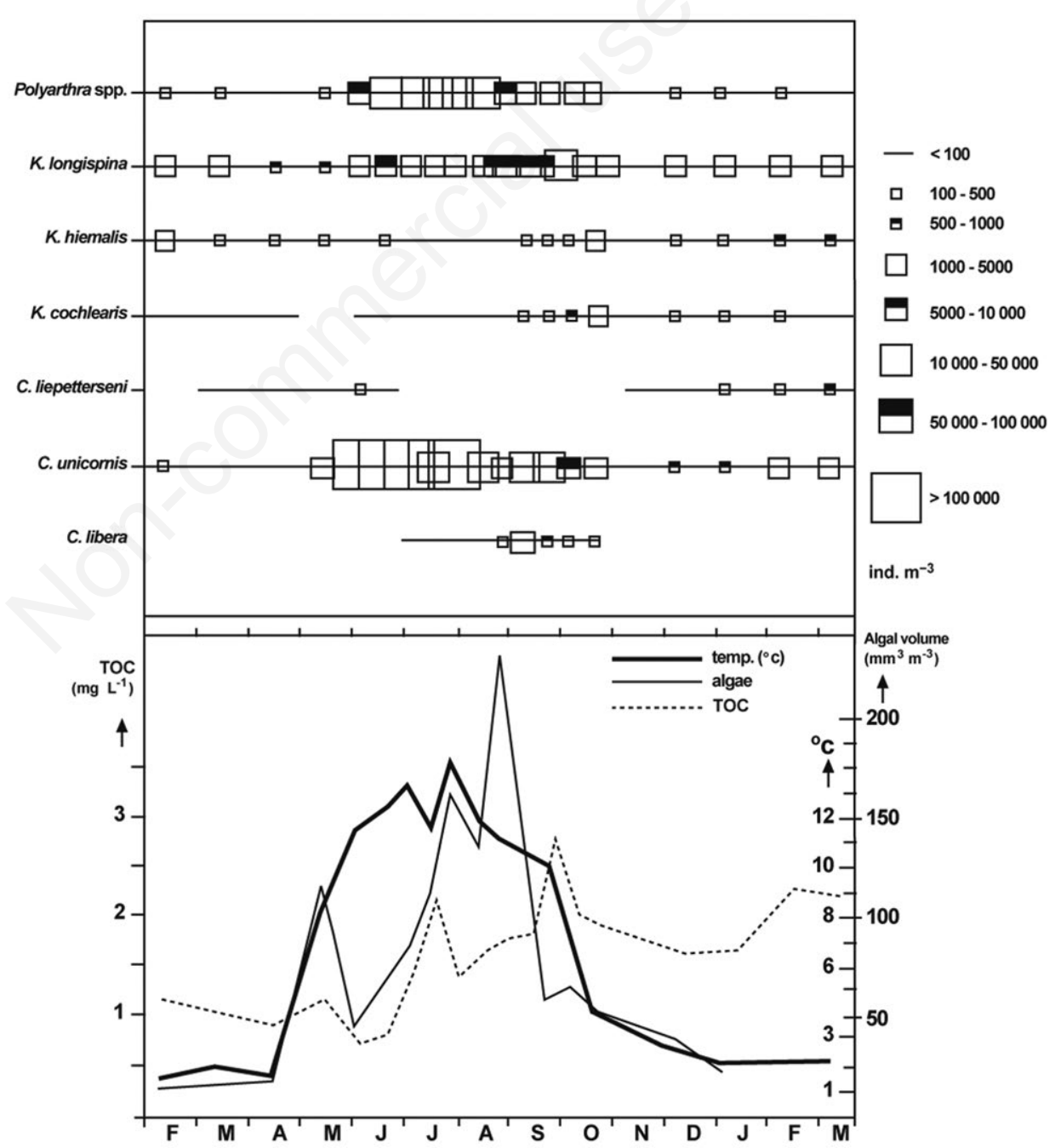

Fig. 8. Total rotifer abundance and their relationship to mean values $\left(0-10 \mathrm{~m}\right.$ depth) of temperature and potential food as algae (mm ${ }^{3}$ $\left.\mathrm{m}^{-3}\right)$ and organic matter calculated as TOC $\left(\mathrm{mg} \mathrm{L}^{-1}\right)$ in Lake Gjerstadvann in 1980/1981. See text for further details. 
Nilssen, 2003; see also Hampton, 2005). Other dominant rotifers in Lake Gjerstadvann were Polyarthra spp. and $K$. longispina, which are commonly found in both chronically acidic and acid-transition lakes in southern Norway (Hobæk and Raddum, 1980; Nilssen, 1980; Sandøy, 1984; Wærvågen and Nilssen, 2003).

The low abundance of $K$. cochlearis in Lake Gjerstadvann may demonstrate its physiological vulnerability to acidified waters, but food availability could also play a decisive role (Havens and De Costa, 1988; Gonzalez and Frost, 1994). It is recorded in very acidic environments in western Sweden and Finland (Arvola et al., 1986; Hörnström and Ekström, 1986; Bērziņš and Pejler, 1987; Morling and Pejler, 1990), but never recorded in high abundance at low $\mathrm{pH}$ in Norway (Hobæk and Raddum, 1980; Wærvågen and Nilssen, 2003). Wærvågen and Nilssen (2003) found that K. cochlearis increased significantly with increasing $\mathrm{pH}$ in many lakes in southern Norway. In North America K. cochlearis was recorded at both low pH (Roff and Kwiatkowski, 1977) and at higher pH levels (Orcutt and Pace, 1984; Siegfried et al., 1984; Carter et al., 1986; Mac Isaac et al., 1987). As observed in $K$. cochlearis, the apparently contrasting ability of tolerance and relationship towards acidic waters may be explained by the existence of populations with different ecological adaptations (Pejler, 1977; Hofmann, 1980; Dumont, 1983; Cieplinski et al., 2017).

\section{Exploitative competition and/or bottom-up relations}

Pelagic freshwater food webs are in general based upon phytoplankton production, especially in clear-water lakes. Consumers in humic lakes may also, by a similar degree, be subsidised by detritus-associated bacterial food (Hessen, 1998). Phytoplankton was a scarce food source in Lake Gjerstadvann, usually well below $200 \mathrm{~mm}^{3} \mathrm{~m}^{-3}$, comparable to chronically acidified lakes (Hindar and Nilssen, 1984; Raddum et al., 1986). Further, the amount of particulate and dissolved humic substances in Lake Gjerstadvann was also limited compared to other oligoto mesohumic lakes (Salonen et al., 1990; Sarvala et al., 1999; see also Brett et al., 2009, 2012, 2017). Resource limitation and food competition may therefore be important factors shaping rotifer populations in Lake Gjerstadvann. Efficient filter-feeder cladocerans can monopolise shared food resources and suppress rotifers (Gilbert, 1988; Mac Isaac and Gilbert, 1989; Sanni and Wærvågen, 1990). The only cladoceran with sufficient abundance to potentially suppress rotifer species in Lake Gjerstadvann was B. longispina, which is found in both fertilised and acidic lakes (Brettum et al., 1984; May, 1995). The omnivorous copepod species E. gracilis was relatively common in Lake Gjerstadvann (Wærvågen and Nilssen, 2010), and could also be able to compete with rotifers during specific parts of the year. The highly significant asso- ciations between rotifer community ordination axes and abundances of both $B$. longispina and E. gracilis could be taken as indications of such competitive relationships. In Lake Gjerstadvann, we found mostly suspension feeders (Conochilus spp., K. longispina and Keratella spp.) following the phytoplankton level maxima in spring and autumn. Furthermore, in the mid-summer and early autumn, the levels of raptorial species (Polyarthra spp., $A$. priodonta and Ascomorpha spp.) peak in near coincidence with TOC-peaks (mostly allochtonous organic matter). Even with some succession overlap, the raptorial Polyarthra spp. peaked together with a cladoceran ( $B$. longispina) in Lake Gjerstadvann, as was also found by Obertegger et al. (2011). Furthermore, algal and detrital food abundance was low in the water masses during June, which could be due to grazing by $B$. longispina at peak abundance.

Keratella cochlearis avoids most rotifers in time and space in Lake Gjerstadvann, probably due to a higher threshold food concentration than the other pure suspension feeders, such as $C$. unicornis and $K$. longispina (Gilbert and Bogdan, 1984). Kellicottia longispina has a lower threshold food concentration than $K$. cochlearis (Walz, 1997), which indicates that $K$. longispina is a superior competitor at lower food levels (Stemberger and Gilbert, 1985). These species can apparently coexist in lakes with sufficient food (Salonen et al., 1990; Sarvala et al., 1999), while under eutrophic conditions $K$. cochlearis was found to be a better competitor than $K$. longispina (Zimmermann, 1974; Sterzynski, 1979; Lair and Oulad Ali, 1990). In other non-acidic neighbouring lakes, $K$. cochlearis was among the dominant rotifer species (Larsen, 1982; Demmo, 1985; Næss, 1985), and outside South Norway it was the dominant rotifer in many non-acidic lakes (Pejler, 1961; Larsson, 1971; Zimmermann, 1974; Eloranta, 1982; Laxhuber, 1987; Andrew and Andrew, 2005; May and O' Hare, 2005). The abundance of rotifers in Lake Gjerstadvann was relatively low compared with a neighbouring lake with similar food availability and very low cladoceran abundance (Sandøy, 1984), in accordance with the highly significant relationship between rotifer community composition and abundance of both B. longispina and E. gracilis.

\section{Predation influence or top-down relations}

Cyclopoid copepods generally exert negative influence on rotifers (Anderson, 1970; Monakov et al., 1972; Vardapetyan, 1972; Gilbert and Williamson, 1978; Karabin, 1978; Brandl and Fernando, 1979; Stemberger, 1985; Plassmann et al., 1997). There is a certain controversy regarding which species of pelagic rotifers are vulnerable to predatory cyclopoid copepods, and whether this applies mainly to soft-bodied forms without lorica (e.g. Synchaeta spp.) (Monakov et al., 1972; Vardapetyan, 1972; 
Plassmann et al., 1997; and references herein), or all sorts of smaller forms irrespective of body structure and the presence of lorica (Karabin, 1978; Walz, 1995; and references in all). The predation indicator from "Cyclopoids" was not significant $(\mathrm{P}=0.493)$ in Lake Gjerstadvann, probably due to the relatively small cyclopoid populations. The abundance of the summer-active, mainly epilimnetic species Thermocyclops oithonoides and Mesocyclops leuckarti (both winter diapausing) was relatively low in Lake Gjerstadvann (Wærvågen and Nilssen, 2010) and several other Norwegian lakes (Nilssen and Wærvågen, 2000). Cyclops scutifer was perennially present in the plankton in Lake Gjerstadvann (Wærvågen and Nilssen, 2010). Despite this, we found no significant predation effects of this species which is known to predate upon rotifers (Monakov et al., 1972; Vardapetyan, 1972). Furthermore, its predatory instars were present in high numbers mainly following ice break when few rotifers normally are present in the plankton. The coloniality tendency in Conochilus probably protects individuals from predation by copepods and carnivorous/omnivorous rotifers (Anderson, 1977; Stemberger and Gilbert, 1987a; Matveeva, 1989; Diéguez and Balseiro, 1998), as for $C$. unicornis in this study. Finally, Lake Gjerstadvann was in a process of continuous acidification at the time of sampling, and some of the cyclopoid species were suffering (Wærvågen and Nilssen, 2010), as was also found in nearby upstream lakes (Sandøy and Nilssen, 1987).

In fishless ecosystems Stenson (1982) found that the abundance of suspension feeders within the rotifers decreased strongly. Under low fish predation, and a potentially high abundance of Chaoborus spp. as a consequence, the latter may exert a strong predation influence on the relative abundance and spatial distribution of their preferred prey rotifers in addition to the total zooplankton community (Nyberg, 1984; Yan et al., 1991; Moore et al., 1994). In Lake Gjerstadvann, such larvae represented the most important fish food item during most of the year (Linløkken, 1988; Vethe, 1988), although they were very seldom collected in the quantitative zooplankton samples (Wærvågen, 1985). We found no significant predation indicator from C. flavicans $(\mathrm{P}=0.410)$ in Lake Gjerstadvann. The species resided mainly in the sediment during daytime, and migrated into the hypolimnion during the night where it was highly selected by both Eurasian perch and brown trout (Vethe, 1988).

\section{CONCLUSIONS}

The major ecological factor influencing rotifer abundance and seasonal occurrence in Lake Gjerstadvann was the perennial low abundance of food, which indicates that resource limitation and food competition are important factors in structuring rotifer seasonal population dynam- ics. The lake has both relatively low allochtonous input of organic matter and low autochtonous pelagic algae production, and therefore the basis for high abundance levels of rotifers in Lake Gjerstadvann was therefore not fulfilled. But, Lake Gjerstadvann still had several common rotifer species present, and possible reasons may be the fact that we found no significant effects of the acidification indicators $\mathrm{pH}$ and $\mathrm{RAl}$ on the total rotifer community in this lake, even though some individual species may have been affected. Furthermore, we found no significant predation indicator from C. flavicans or predator stages of cyclopoid copepods (Cop IV-adult stages). The most significant competition indicator species were $B$. longispina and E. gracilis, in good accordance with their dominance as cladoceran and copepod species in Lake Gjerstadvann, respectively (Wærvågen and Nilssen, 2010, 2011). Among the highly significant environmental gradient indicators were temperature and oxygen, illustrating the important effects of the seasonal cycle and vertical density stratification in the rotifer community.

\section{ACKNOWLEDGMENTS}

This study was undertaken at the Biological Institute, Zoological Division, at the University of Oslo, Norway. We are grateful to Frode Kroglund, Steinar Sandøy and Anne Skov for helpful field cooperation. We would like to give special thanks to Jens Petter Nilssen for sharing his encyclopedic knowledge on species ecology and systematics. Further, we are thankful to Erling Brekke for identifying species of the Lecane genus, to Gro Lindberg and Bård Gunnerud-Åhlén for digitalising the figures and to Robert Wilson for proofreading the manuscript. We acknowledge the anonymous reviewers for their valuable comments and suggestions that clarified the paper.

\section{REFERENCES}

Almer B, Dickson W, Ekstrom C, Hornstrom E, Miller U, 1974. Effects of acidification on Swedish lakes. Ambio 3:30-36.

Anderson RS, 1970. Predator-prey relationships and predation rates for crustacean zooplankters from some lakes in western Canada. Can. J. Zool. 48:1229-1240.

Anderson RS, 1977. Rotifer populations in mountain lakes relative to fish and species of copepods present. Arch. Hydrobiol. Beih. 8:130-134.

Andrew TE, Andrew JAM, 2005. Seasonality of rotifers and temperature in Lough Neagh, N. Ireland. Hydrobiologia 546:451-455.

Armengol-Díaz J, Esparcia A, Vicente E, Miracle MR, 1993. Vertical distribution of planktonic rotifers in a karstic meromictic lake. Hydrobiologia 255/256:381-388.

Armengol X, Esparcia A, Miracle MR, 1998. Rotifer vertical distribution in a strongly stratified lake: a multivariate analysis. Hydrobiologia 387:161-170. 
Arndt H, 1993. Rotifers as predators on components of the microbial web (bacteria, heterotrophic flagellates, ciliates) - a review. Hydrobiologia 255/256:231-246.

Arvola L, Salonen K, Bergström I, Heinänen A, Ojala A, 1986. Effects of experimental acidification on phytoplankton, bacterioplankton and zooplankton in enclosures of a highly humic lake. Int. Rev. Gesamt. Hydrobiol. 71:737-758.

Bartumeus F, Catalan J, 2008. Niche segregation factors in an assemblage of pelagic rotifers of a deep high-mountain lake (Redon, Pyrenees). J. Plankton Res. 30:709-721.

Bērziņš B, 1976. [Med urtidshjul i rymdåldern].[Article in Swedish]. Aquannalen, Societas Aquatica Lundensis 1:2-10.

Bērziņš B, Pejler B, 1987. Rotifer occurrence in relation to $\mathrm{pH}$. Hydrobiologia 147:107-116.

Borcard D, Legendre P, Drapeau P, 1992. Partialling out the spatial component of ecological variation. Ecology 73:1045-1055.

Bottrell HH, Duncan A, Gliwicz ZM, Grygierek E, Herzig A, Hillbricht-Ilkowska A, Kurasawa H, Larsson P, Weglenska T, 1976. A review of some problems in zooplankton production studies. Norw. J. Zool. 24:419-456.

Brandl Z, 2005. Freshwater copepods and rotifers: predators and their prey. Hydrobiologia 546:475-489.

Brandl Z, Fernando CH, 1979. The impact of predation by the copepod Mesocyclops edax (Forbes) on zooplankton in three lakes in Ontario, Canada. Can. J. Zool. 57:940-942.

Brett MT, Arhonditsis GB, Chandra S, Kainz MJ, 2012. Mass flux calculations show strong allochthonous support of freshwater zooplankton production is unlikely. PloS One 7:e39508.

Brett MT, Bunn SE, Chandra S, Galloway AWE, Guo F, Kainz MJ, Kankaala P, Lau DCP, Moulton TP, Power ME, 2017. How important are terrestrial organic carbon inputs for secondary production in freshwater ecosystems? Freshwater Biol. 62:833-853.

Brett MT, Kainz MJ, Taipale SJ, Seshan H, 2009. Phytoplankton, not allochthonous carbon, sustains herbivorous zooplankton production. P. Natl. Acad. Sci. USA 106:21197-21201.

Brettum P, Kroglund F, Nilssen JP, Sandøy S, Skov A, Wærvågen SB, 1984. [Eksperimentelle innhegningsforsøk i Gjerstad, Aust-Agder. Et forsøk på alternativ behandling av sure vann], p. 1-78.[Report in Norwegian]. Rep. Norw. Liming Project 16-1984.

Carlin B, 1943. [Die Planktonrotatorien des Motalaström: zur Taxonomie und Ökologie der Planktonrotatorien].[Book in German]. Medd. Lunds Univ. Limnol. Instm: 256 pp.

Carter JCH, Taylor WD, Chengalath R, Scruton DA, 1986. Limnetic zooplankton assemblages in Atlantic Canada with special reference to acidification. Can. J. Fish. Aquat. Sci. 43:444-456.

Cieplinski A, Weisse T, Obertegger U, 2017. High diversity in Keratella cochlearis (Rotifera, Monogononta): morphological and genetic evidence. Hydrobiologia 756:145-159.

Degerman E, 1987. [Humösa sjöar. En litteratursammanställning med inriktning på fisk och försurning], p. 1-72. [Report in Swedish with English summary]. Report 3415, Statens Naturvårdsverk: 72 pp.

Demmo R, 1985. [En undersøkelse av zooplanktonsamfunnene i Bosvikkilen. En limnisk og en marin lokalitet ved Risør i Aust-Agder].[Master's Thesis in Norwegian], University of Oslo.

Diéguez M, Balseiro E, 1998. Colony size in Conochilus hippocrepis: defensive adaptation to predator size. Hydrobiologia 387/388:421-425.

Drabløs D, Tollan A, 1980. Ecological impact of acid precipitation. SNSF-project. Ås-NLH: 383 pp.

Dumont HJ, 1983. Biogeography of rotifers. Hydrobiologia 104:19-30.

Duncan A, 1989. Food limitation and body size in the life cycles of planktonic rotifers and cladocerans. Hydrobiologia 186:11-28.

Einsle U, 1975. [Revision der Gattung Cyclops s.str., speziell der abyssorum-Gruppe].[Article in German]. Mem. Ist. Ital. Idrobiol. 32:57-219.

Elliott JI, 1977. Seasonal changes in the abundance and distribution of planktonic rotifers in Grasmere (English Lake District). Freshwater Biol. 7:147-166.

Eloranta PV, 1982. Zooplankton in the Vasikkalampi pond, a warm water effluent recipient in Central Finland. J. Plankton Res. 4:813-837.

Eriksson MOG, Henrikson L, Nilsson BI, Nyman G, Oscarson HG, Stenson AE, Larsson K, 1980. Predator-prey relations important for the biotic changes in acidified lakes. Ambio 9:248-249.

Fjerdingstad E, Nilssen JP, 1982. Bacteriological and hydrological studies on acidic lakes in Southern Norway. Arch. Hydrobiol. 64:443-483.

Flößner D, 1972. [Krebstiere, Crustacea; Kiemen-und Blattfüßer, Branchiopoda; Fischläuse, Branchiura. Die Tierwelt Deutschlands. 60 Teil].[Book in German]. G. Fischer Verlag, Jena: $501 \mathrm{pp}$.

Frost TM, Montz PK, Gonzalez MJ, Sanderson BL, Arnott SE, 1998. Rotifer responses to increased acidity: long-term patterns during the experimental manipulation of Little Rock Lake. Hydrobiologia 387:141-152.

Gilbert JJ, 1988. Suppression of rotifer populations by Daphnia: a review of the evidence, the mechanisms, and the effects on zooplankton community structure. Limnol. Oceanogr. 33:1286-1303.

Gilbert JJ, Bogdan KG, 1984. Rotifer grazing: In situ studies on selectivity and rates, p. 97-133. In: D.G. Meyers and J.R. Strickler (eds.), Trophic interactions within aquatic ecosystems. American Association for the Advancement of Science, Special Symposium 85, Boulder.

Gilbert JJ, Williamson CE, 1978. Predator-prey behavior and its effect on rotifer survival in associations of Mesocyclops edax, Asplanchna girodi, Polyarthra vulgaris, and Keratella cochlearis. Oecologia (Berl.) 37:13-22.

Gonzalez MJ, Frost TM, 1992. Food limitation and seasonal population declines of rotifers. Oecologia 89:560-566.

Gonzalez MJ, Frost TM, 1994. Comparisons of laboratory bioassays and a whole-lake experiment: Rotifer responses to experimental acidification. Ecol. Appl. 4:69-80.

Hampton SE, 2005. Increased niche differentiation between two Conochilus species over 33 years of climate change and food web alteration. Limnol. Oceanogr. 50:421-426.

Havens KE, De Costa J, 1988. An experimental analysis of the acid sensitivity of the common planktonic rotifer Keratella cochlearis. Int. Rev. Gesamt. Hydrobiol. 73:407-416.

Havens KE, Heath RT, 1989. Acid and aluminum effects on freshwater zooplankton: an in situ mesocosm study. Environ. Pollut. 62:195-211. 
Henriksen A, 1979. A simple approach for identifying and measuring acidification of freshwater. Nature 278:542-545.

Henriksen A, 1980. Acidification of freshwaters - a large scale titration, p. 68-74. In: D. Drabløs and A. Tollan (eds.), Ecological impact of acid precipitation. SNSF-project. Ås-NLH.

Herzig A, 1983. Comparative studies on the relationship between temperature and duration of embryonic development of rotifers. Hydrobiologia 104:237-246.

Herzig A, 1987. The analysis of planktonic rotifer populations: A plea for long-term investigations. Hydrobiologia 147:163-180.

Hessen DO, 1998. Food webs and carbon cycling in humic lakes, p. 285-315. In: D.O. Hessen and L. Tranvik (eds.), Aquatic humic substances, ecology and biochemistry. Springer, Berlin.

Hindar A, Kroglund F, Nilssen JP, Sandøy S, Skov A, Smestad O, Wærvågen SB, 1984. [Elvedata fra Gjerstad, Aust-Agder. En vannkjemisk datarapport], p. 1-47. [Report in Norwegian]. Rep. Norw. Liming Project 15-1984.

Hindar A, Nilssen JP, 1984. [Årsrapport Gjerstad 1982/84], p. 1-153. [Report in Norwegian]. Rep. Norw. Liming Project 21-1984.

Hobæk A, Raddum GG, 1980. Zooplankton communities in acidified lakes in South Norway, p. 132. SNSF-project, IR $75 / 80$.

Hofmann W, 1980. On morphological variation in Keratella cochlearis populations from Holstein lakes (Northern Germany). Hydrobiologia 73:255-258.

Hofmann W, 1987. Population dynamics of hypolimnetic rotifers in the Pluss-see (North Germany). Hydrobiologia 147:197-201.

Holopainen IJ, 1992. The effects of low pH on planktonic communities. Case history of a small forest pond in eastern Finland. Ann. Zool. Fenn. 28:95-103.

Hörnström E, Ekström C, 1986. Acidification and liming effects on phyto- and zooplankton in some Swedish West Coast lakes. Report 1864, Swedish Environ. Protect., Solna, Sweden.

Karabin A, 1978. The pressure of pelagic predators of the genus Mesocyclops (Copepoda, Crustacea) on small zooplankton. Ekol. Polska 26:241-257.

Keller W, Gunn JM, Yan ND, 1999. Acid rain - perspectives on lake recovery. J. Aquat. Ecosyst. Stress Recov. 6:207-216.

Keller W, Yan ND, Howell T, Molot LA, Taylor WD, 1992. Changes in zooplankton during the experimental neutralization and early reacidification of Bowland Lake near Sudbury, Ontario. Can. J. Fish. Aquat. Sci. 49:52-62.

Kiefer F, 1978. [Das Zooplankton der Binnengewässer. Freilebende Copepoda].[Book in German]. E. Schweizerbart'sche Verlag, Stuttgart: 380 pp.

Kirk KL, 1997a. Egg size, offspring quality and food level in planktonic rotifers. Freshwater Biol. 37:515-521.

Kirk KL, 1997b. Life history responses to variable environments: Starvation and reproduction in planktonic rotifers. Ecology 78:434-441.

Kleiven E, Matzow D, Linløkken A, Vethe A, 1990. [Regionale fiskeundersøkjingar i Gjerstadvassdraget].[Report in Norwegian].DN-notat 8/1990: 52 pp.

Koste W, Voigt M, 1978. [Rotatoria: Die Rädertiere Mitteleuropas. 2].[Book in German]. Gebrüder Borntraeger, Berlin: 673 pp.

Lair N, Oulad Ali H, 1990. Grazing and assimilation rates of natural populations of planktonic rotifers Keratella cochlearis,
Keratella quadrata and Kellicottia longispina in a eutrophic lake (Aydat, France). Hydrobiologia 194:119-131.

Larsen DA, 1982. [Populasjonsdynamikk til zooplankton i Fievann, et mixotroft kystvann i Aust-Agder, med spesiell vekt på konkurranse og predasjon som regulerende faktorer].[Master's Thesis in Norwegian], University of Oslo.

Larsson P, 1971. Vertical distribution of planktonic rotifers in a meromictic lake; Blankvatn near Oslo, Norway. Norw. J. Zool. 19:47-75.

Larsson P, 1978. The life cycle dynamics and production of zooplankton in Ovre Heimdalsvatn. Holartic Ecol. 1:162-218.

Laxhuber R, 1987. Abundance and distribution of pelagic rotifers in a cold, deep oligotrophic alpine lake (Königssee). Hydrobiologia 147:189-196.

Linløkken A, 1985. [Populasjonsbiologi hos aure, sik, røye og abbor i det forsurningstrua Gjerstadvann].[Master's Thesis in Norwegian], University of Oslo.

Linløkken A, 1988. Vertical distribution of brown trout (Salmo Trutta) and perch (Perca fluviatilis) in an acidified lake. Water Air Soil Poll.40:203-213.

Linløkken A, Kleiven E, Matzow D, 1991. Population structure, growth and fecundity of perch (Perca fluviatilis L.) in an acidified river system in Southern Norway. Hydrobiologia 220:179-188.

Lydersen E, 1998. Humus and acidification, p. 63-92. In: D.O. Hessen and L. Tranvik (eds.), Aquatic humic substances, ecology and biochemistry. Springer, Berlin.

Mac Isaac HJ, Gilbert JJ, 1989. Competition between rotifers and cladocerans of different body sizes. Oecologia (Berl.) 81:295-301.

Mac Isaac HJ, Hutchinson TC, Keller W, 1987. Analysis of planktonic rotifer assemblages from Sudbury, Ontario, area lakes of varying chemical composition. Can. J. Fish. Aquat. Sci. 44:1692-1701.

Makarewicz JC, Likens GE, 1975. Niche analysis of a zooplankton community. Science 190:1000-1003.

Marmorek DR, Korman J, 1993. The use of zooplankton in a biomonitoring program to detect lake acidification and recovery. Water Air Soil Pollut. 69:223-241.

Matveeva LK, 1989. Interrelations of rotifers with predatory and herbivorous Cladocera: a review of Russian works. Hydrobiologia 186/187:69-73.

May L, 1995. The effect of lake fertilisation on the rotifers of Seathwaite Tarn, an acidified lake in the English Lake District. Hydrobiologia 313/314:333-340.

May L, O'Hare M, 2005. Changes in rotifer species composition and abundance along a trophic gradient in Loch Lomond, Scotland, UK. Hydrobiologia 546:397-404.

Mikschi E, 1989. Rotifer distribution in relation to temperature and oxygen content. Hydrobiologia 186:209-214.

Minchin PR, 1987. An evaluation of the relative robustness of techniques for ecological ordination. Vegetatio 69:89-107.

Monakov AV, Nosova IA, Sorokin YI, 1972. [On the food of Cyclops scutifer].[Article in Russian]. Biol. Inland Waters Inf. Bull. 13:27-31.

Moore MV, Yan ND, Pawson T, 1994. Omnivory of the larval phantom midge (Chaoborus spp.) and its potential significance for freshwater planktonic food webs. Can. J. Zool. 72:2055-2065.

Morling G, Pejler B, 1990. Acidification and zooplankton de- 
velopment in some West-Swedish lakes 1966-1983. Limnologica (Berl.) 20:307-318.

Nauwerck A, 1963. [Die Beziehungen zwischen Zooplankton und Phytoplankton im See Erken].[Book in German]. Symb. Bot. Upsal. 17:1-163.

Nilssen JP, 1980. Acidification of a small watershed in southern Norway and some characteristics of acidic aquatic environments. Int. Rev. Gesamt. Hydrobiol. 65:177-207.

Nilssen JP, 1982a. Acidification in southern Norway: seasonal variation of aluminum in lake waters. Hydrobiologia 94:217-221.

Nilssen JP, 1982b. [La détection de l’acidification régionale des lacs et de ses causes].[Article in French]. Eau du Québec 15:335-341.

Nilssen JP, 1984. An ecological jig-saw puzzle: reconstructing aquatic biogeography and $\mathrm{pH}$ in an acidified region. Report Institute of Freshwater Research, Drottningholm 61:138-147.

Nilssen JP, Sandøy S, 1990. Recent lake acidification and cladoceran dynamics: surface sediment and core analyses from lakes in Norway, Scotland and Sweden. Philos. T. R. Soc. B 327:299-309.

Nilssen JP, Wærvågen SB, 2000. Superficial ecosystem similarities vs autecological stripping: the "twin species" Mesocyclops leuckarti (Claus) and Thermocyclops oithonoides (Sars)-seasonal habitat utilisation and life history traits. J. Limnol. 59:79-102.

Nilssen JP, Wærvågen SB, 2001. [Kjemisk og biologisk «recovery» av forsurede innsjøer i Aust-Agder. Kalkede vann og referansevann i 1999 og 2000]. [Report in Norwegian]. Rapport nr. 2 - 2001, Fylkesmannen i Aust-Agder: 80 pp.

Nilssen JP, Wærvågen SB, 2002a. Intensive fish predation: an obstacle to biological recovery following liming of acidified lakes? J. Aquat. Ecosyst. Stress Recov. 9:73-84.

Nilssen JP, Wærvågen SB, 2002b. Recent re-establishment of the key species Daphnia longispina and cladoceran community changes following chemical recovery in a strongly acidstressed region in southern Norway. Arch. Hydrobiol. 153:557-580

Nilssen JP, Wærvågen SB, 2003. Ecological distribution of pelagic copepods and species relationship to acidification, liming and natural recovery in a boreal area. J. Limnol. 62:97-114.

Nipkow F, 1961. [Die Rädertiere im Plankton des Zürichsees und ihre Entwicklungsphasen].[Article in German]. Schweiz. Zeitsch. Hydrol. 23:398-461.

Nogrady T, Wallace RL, Snell TW, 1993. Rotifera. 1. In: T. Nogrady and H.J.F. Dumont (eds.), Biology, ecology and systematics. Guides to the identification of the microinvertebrates of the continental waters of the world. SPB Academic Publishing, The Hague.

Nyberg K, Raitaniemi J, Rask M, Mannio J, Vuorenmaa J, 1995. What can perch population data tell us about the acidification history of a lake? Water Air Soil Pollut. 85:395-400.

Nyberg P, 1984. Impact of Chaoborus predation on planktonic crustacean communities in some acidified and limed forest lakes in Sweden. Report Institute of Freshwater Research, Drottningholm 61:154-166.

Nyman HG, Oscarson HG, Stenson JAE, 1985. Impact of invertebrate predators on the zooplankton composition in acid forest lakes. Ecological Bulletins (Stockh.) 37:239-243.
Næss T, 1985. [En undersøkelse av zooplanktonsamfunnene i Vormelitjenn og Søndeledpollen, en limnisk og marin lokalitet ved Søndeled i Aust-Agder].[Master's Thesis in Norwegian], University of Oslo.

Obertegger U, Flaim G, Sommaruga R, 2008. Multifactorial nature of rotifer water layer preferences in an oligotrophic lake. J. Plankton Res. 30:633-643.

Obertegger U, Smith HA, Flaim G, Wallace RL, 2011. Using the guild ratio to characterize pelagic rotifer communities. Hydrobiologia 662:157-162.

Oksanen J, Blanchet FG, Kindt R, Legendre P, Minchin PR, O'Hara RB, Simpson GL, Solymos P, Henry M, Stevens H, Wagner H, 2013. vegan: Community Ecology Package. R package version 2.4-4. Community ecology package, version 2.

Orcutt JD, Pace ML, 1984. Seasonal dynamics of rotifer and crustacean zooplankton populations in a eutrophic, monomictic lake with a note on rotifer sampling techniques. Hydrobiologia 119:73-80.

Pejler B, 1961. The zooplankton of Ösbysjön, Djursholm. I. Seasonal and vertical distribution of the species. Oikos 12:225-248.

Pejler B, 1977. On the global distribution of the family Brachionidae (Rotatoria). Arch. Hydrobiol. Suppl. 53:255-306.

Plassmann T, Maier G, Stich HB, 1997. Predation impact of $C y$ clops vicinus on the rotifer community in Lake Constance in spring. J. Plankton Res. 19:1069-1079.

Pontin RM, 1978. A key to the freshwater planktonic and semiplanktonic Rotifera of the British Isles. Freshwater Biological Association, Windermere: 178 pp.

Raddum GG, Brettum P, Matzow D, Nilssen JP, Skov A, Sveälv T, Wright RF, 1986. Liming the acid Lake Hovvatn, Norway: A whole-ecosystem study. Water Air Soil Pollut. 31:721-763.

Roff JC, Kwiatkowski RE, 1977. Zooplankton and zoobenthos communities of selected northern Ontario lakes of different acidities. Can. J. Zool. 55:899-911.

Ruttner-Kolisko A, 1972. [Rotatoria], p. 99-234. In: H.J. Elster and W. Ohle (eds.), [Die Binnengewässer Band 26, Das Zooplankton der Binnengewässer].[Book in German]. Schweizerbart'sche Verlag, Stuttgart.

Ruttner F, 1930. [Das Plankton des Lunzer Untersees seine Verteilung in Raum und Zeit während der Jahre 1908-1913]. Int. Rev. Ges. Hydrobio. 23:211-260.

Rylov VM, 1963. Freshwater Cyclopoida. Fauna of the USSR. Crustacea. 3. [Translated from Russian]. Israel Program for Scientific Translations, Jerusalem: 313 pp.

Salonen K, Järvinen M, Kuoppamäki K, Arvola L, 1990. Effects of liming on the chemistry and biology of a small acid humic lake, p. 1145-1167. In: P. Kauppi, K. Kenttämies and P. Anttila (eds.), Acidification in Finland. Springer, Berlin.

Sandøy S, 1984. [Zooplanktonsamfunnet i to forsura vatn i Gjerstad i Aust-Agder. Virkning av biotiske og abiotiske faktorar på livssyklus og populasjonstetthet].[Master's Thesis in Norwegian], University of Oslo.

Sandøy S, Nilssen JP, 1987. Cyclopoid copepods in marginal habitats: Abiotic control of population densities in anthropogenic acidic lakes. Arch. Hydrobiol. Suppl. 76:236-255.

Sanni S, Wærvågen SB, 1990. Oligotrophication as a result of planktivorous fish removal with rotenone in the small, eu- 
trophic, Lake Mosvatn, Norway. Hydrobiologia 200201:263-274.

Sarma SSS, Gulati RD, Nandini S, 2005. Factors affecting eggratio in planktonic rotifers. Hydrobiologia 548:361-373.

Sarvala J, Kankaala P, Zingel P, Arvola L, 1999. Zooplankton, p. 173-191. In: J. Keskitalo and P. Eloranta (eds.), Limnology of humic waters. Backhuys Publishers, Leiden.

Schindler DW, 1969. Two useful devices for vertical plankton and water sampling. J. Fish. Res. Board Can. 26:1948-1955.

Siegfried CA, 1991. The pelagic rotifer community of an acidic clearwater lake in the Adirondack Mountains of New York State. Arch. Hydrobiol. 122:441-462.

Siegfried CA, Sutherland JW, Quinn SO, Bloomfield JA, 1984. Lake acidification and the biology of Adirondack lakes: I. Rotifer communities. Verh. Int. Ver. Limnol. 22:549-558.

Skadovsky SN, 1926. [Über die aktuelle Reaktion der Süsswasserbecken und ihre biologische Bedeutung].[Article in German]. Verh. Int. Ver. Limnol. 3:109-144.

Skadovsky SN, 1933. [Die Biologie des Planktons und die physikalisch-chemische Verhältnisse in den Petrowski-Seen des Torfmassiws Orscha im Muskauer Gebiet].[Article in Russian with German Abstract]. Zoologeskij J. 12:4-26.

Stelzer C-P, 2005. Evolution of rotifer life histories. Hydrobiologia 546:335-346.

Stemberger RS, 1985. Prey selection by the copepod Diacyclops thomasi. Oecologia (Berl.) 65:492-497.

Stemberger RS, Gilbert JJ, 1985. Body size, food concentration, and population growth in planktonic rotifers. Ecology 66:1151-1159.

Stemberger RS, Gilbert JJ, 1987a. Defenses of planktonic rotifers against predators, p. 227-239. In: W.C. Kerfoot and A. Sih (eds.), Predation: Direct and indirect impacts on aquatic communities. New England University Press, Hanover.

Stemberger RS, Gilbert JJ, 1987b. Rotifer threshold food concentrations and the size-efficiency hypothesis. Ecology 68:181-187.

Stenson JAE, 1982. Fish impact on rotifer community structure. Hydrobiologia 87:57-64.

Stenson JAE, 1983. Changes in the relative abundance of Polyarthra vulgaris and P. dolichoptera, following the elimination of fish. Hydrobiologia 104:269-273.

Stenson JAE, Svensson J-E, Cronberg G, 1993. Changes and interactions in the pelagic community in acidified lakes in Sweden. Ambio 22:277-282.

Sterzynski W, 1979. Fecundity and body size of planktic rotifers in 30 Polish lakes of various trophic state. Ekol. Polska 27:307-321.
Svensson J-E, Stenson JAE, 2002. Responses of planktonic rotifers to restoration measures: trophic cascades after liming in Lake Gårdsjön. Arch. Hydrobiol. 153:301-322.

Synnes K, 1982. [En sammenlikning av zooplanktonsamfunnene i Myrkdalsvatnet og Oppheimsvatnet på Voss].[Master's Thesis in Norwegian], University of Oslo.

Vandysh OI, 2002. Effect of acidification on zooplankton communities of small lakes in mountain tundra. Water Res. 29:554-560.

Vardapetyan SM, 1972. Food relations of predatory crustaceans in lake zooplankton. Sov. J. Ecol. 3:222-227.

Vethe A, 1988. [Sesongvariasjon i habitatfordeling og næringsval til abbor og aure i eit forsuringstrua vatn i SørNoreg].[Master's Thesis in Norwegian], University of Oslo.

Walz N, 1993. Life history strategies of rotifers, p. 193-214. In: N. Walz (ed.), Plankton regulation dynamics. Elements and models in rotifers continuous cultures. Springer, Berlin.

Walz N, 1995. Rotifer populations in plankton communities: energetics and life history strategies. Experientia 51:437-453.

Walz N, 1997. Rotifer life history strategies and evolution in freshwater plankton communities, p. 119-149. In: B. Streit, T. Städler and C.M. Lively (eds.), Evolutionary ecology of freshwater animals. Birkhäuser Verlag, Basel.

Wærvågen SB, 1985. [En limnologisk studie av Gjerstadvann i Aust-Agder, med spesiell vekt på zooplanktonsamfunnets livshistorier og populasjonsdynamikk].[Master's Thesis in Norwegian], University of Oslo.

Wærvågen SB, Nilssen JP, 2003. Major changes in pelagic rotifers during natural and forced recovery from acidification. Hydrobiologia 499:63-82.

Wærvågen SB, Nilssen JP, 2010. Life histories and seasonal dynamics of common boreal pelagic copepods (Crustacea, Copepoda) inhabiting an oligotrophic Fennoscandian lake. J. Limnol. 69:311-332.

Wærvågen SB, Nilssen JP, 2011. Seasonal dynamics and life histories of pelagic cladocerans (Crustacea; Cladocera) in an acid boreal lake. J. Limnol. 70:83-101.

Yan ND, Geiling W, 1985. Elevated planktonic rotifer biomass in acidified metal-contaminated lakes near Sudbury, Ontario. Hydrobiologia 120:199-205.

Yan ND, Keller W, MacIsaac HJ, McEachern LJ, 1991. Regulation of zooplankton community structure of an acidified lake by Chaoborus. Ecol. Appl. 1:52-65.

Zimmermann C, 1974. [Die pelagischen Rotatorien des Sempachersees, mit spezieller Berücksichtigung der Brachioniden und der Ernährungsfrage].[Article in German]. Schweiz. Z. Hydrol. 36:205-300. 